\title{
Review \\ Periodontal and Dental Pulp Cell-Derived Small Extracellular Vesicles: A Review of the Current Status
}

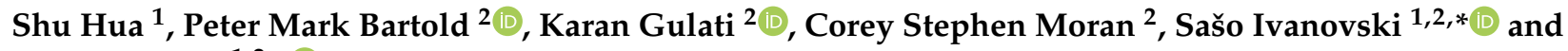 \\ Pingping Han $1,2, *$ (D) \\ 1 Epigenetics Nanodiagnostic and Therapeutic Group, Center for Orofacial Regeneration, Rehabilitation and \\ Reconstruction (COR3), School of Dentistry, Faculty of Health and Behavioural Sciences, \\ The University of Queensland, Brisbane, QLD 4006, Australia; s.hua@uq.net.au \\ 2 School of Dentistry, The University of Queensland, Brisbane, QLD 4006, Australia; \\ mark.bartold@adelaide.edu.au (P.M.B.); k.gulati@uq.edu.au (K.G.); corey.moran@uq.edu.au (C.S.M.) \\ * Correspondence: s.ivanovski@uq.edu.au (S.I.); p.han@uq.edu.au (P.H.)
}

check for updates

Citation: Hua, S.; Bartold, P.M.; Gulati, K.; Moran, C.S.; Ivanovski, S.; Han, P. Periodontal and Dental Pulp Cell-Derived Small Extracellular Vesicles: A Review of the Current Status. Nanomaterials 2021, 11, 1858 . https://doi.org/10.3390/ nano11071858

Academic Editor:

Alicia Rodríguez-Gascón

Received: 23 June 2021

Accepted: 15 July 2021

Published: 19 July 2021

Publisher's Note: MDPI stays neutral with regard to jurisdictional claims in published maps and institutional affiliations.

\begin{abstract}
Extracellular vesicles (EVs) are membrane-bound lipid particles that are secreted by all cell types and function as cell-to-cell communicators through their cargos of protein, nucleic acid, lipids, and metabolites, which are derived from their parent cells. There is limited information on the isolation and the emerging therapeutic role of periodontal and dental pulp cell-derived small EVs (sEVs, $<200 \mathrm{~nm}$, or exosome). In this review, we discuss the biogenesis of three EV subtypes (sEVs, microvesicles and apoptotic bodies) and the emerging role of sEVs from periodontal ligament (stem) cells, gingival fibroblasts (or gingival mesenchymal stem cells) and dental pulp cells, and their therapeutic potential in vitro and in vivo. A review of the relevant methodology found that precipitation-based kits and ultracentrifugation are the two most common methods to isolate periodontal (dental pulp) cell sEVs. Periodontal (and pulp) cell sEVs range in size, from $40 \mathrm{~nm}$ to $2 \mu \mathrm{m}$, due to a lack of standardized isolation protocols. Nevertheless, our review found that these EVs possess anti-inflammatory, osteo/odontogenic, angiogenic and immunomodulatory functions in vitro and in vivo, via reported EV cargos of EV-miRNAs, EV-circRNAs, EV-mRNAs and EV-lncRNAs. This review highlights the considerable therapeutic potential of periodontal and dental pulp cell-derived sEVs in various regenerative applications.
\end{abstract}

Keywords: extracellular vesicles; exosomes; nanomedicine; regeneration; cell-free therapy

\section{Introduction}

Extracellular vesicles (EVs) are membrane-bound bilayered lipid particles that are secreted from both prokaryotic and eukaryotic cells, carrying a cargo of biological molecules (i.e., protein, nucleic acid, lipids and metabolites) from their parent cells [1]. Initially, EVs were considered 'cellular dust', generated by cellular metabolism, until their biological role in the mineralization of bone was recognized [2,3]. A principal role of EVs is as an intercellular communicator of biological information into a recipient cell. This interaction can trigger signaling cascades and modulate cell behavior [4]. The biological function of EVs is defined by the parent cells from which they originate. EVs are involved in almost all cellular interactions, especially tumor metastasis, tissue homeostasis, and inflammatory regulation [4,5]. Due to their constituent biological molecules, EVs hold great promise as a therapeutic delivery system in regenerative medicine.

The definition, terminology and subtypes of EVs are still being debated. The International Society of Extracellular Vesicles (ISEV) recommends a division of EV subtypes based on their size: medium/large EV (>150 nm) and small EV (<150 nm) [6]. However, considering the discrepancies in the published literature, for simplification purposes, this review will define EV subtypes based on both their size and biogenesis (Figure 1a): small extracellular vesicles (also known as exosomes) (sEVs, <200 nm), microvesicles (MVs, 
50-1000 nm) and apoptotic bodies (ApoBDs, 50-2000 nm). Furthermore, it is noteworthy that all EVs have various membrane proteins (e.g., tetraspanin, MHC, and HSP) and components (e.g., dsDNA, RNA, microRNA, circular RNA [7], and proteins) (Figure 1b).
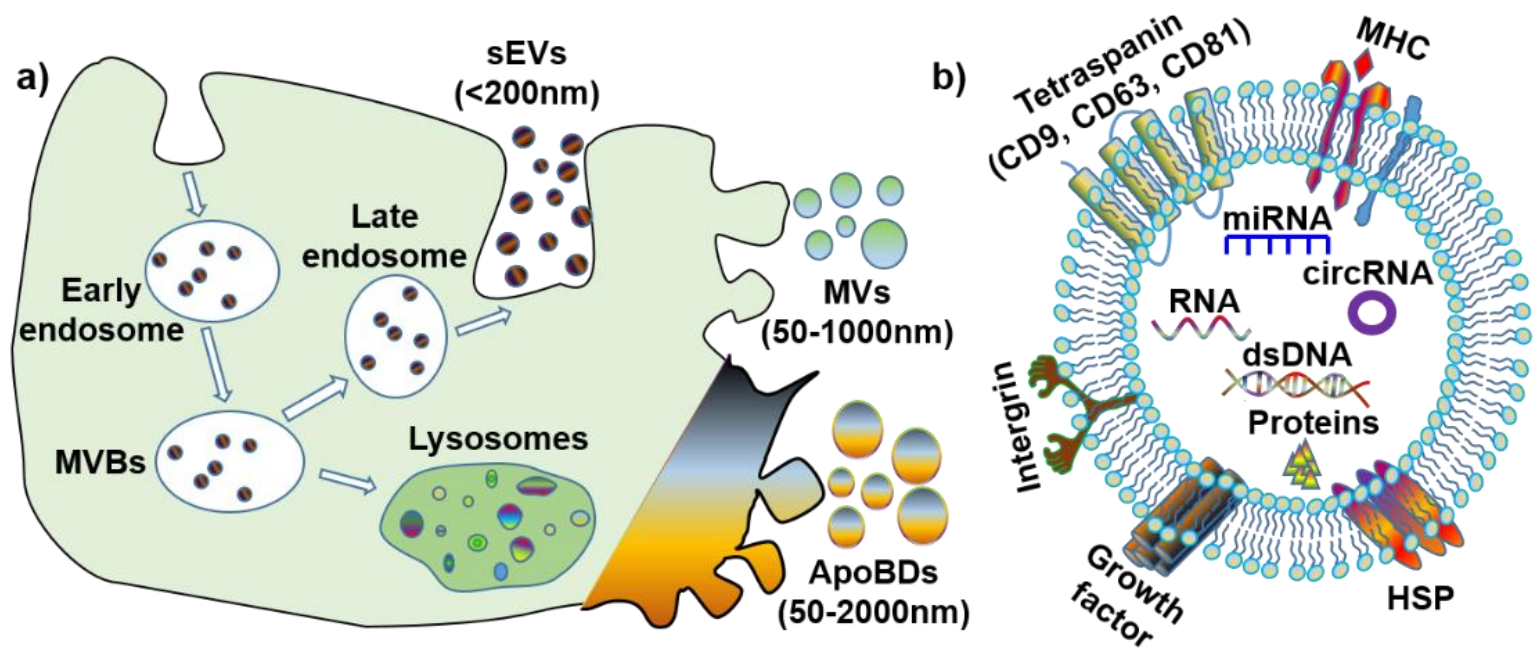

Figure 1. The biogenesis and contents of extracellular vesicles (EVs). (a) Biogenesis and size of three EV subtypes. (b) Common surface markers and cargos of EVs. sEVs: small extracellular vesicles; MVs: microvesicles; ApoBDs: apoptotic bodies; MVBs: multi-vesicular bodies; MHC: major histocompatibility complex; HSP: heat-shock protein; dsDNA: doublestranded DNA; miRNA: microRNA; circRNA: circular RNA.

\subsection{Small EV (Exosomes)}

Small EVs (sEV), or exosomes, originate from endosomes, and are biological nanoparticles that are smaller than $200 \mathrm{~nm}$ [5]. Further, sEVs are produced through an endocytic pathway, and their particle size is partially overlaid with that of microvesicles and apoptotic bodies. The biogenesis process for $\mathrm{sEV}$ is unique, whereby the endosomal network is the source of sEV that produce, classify, distribute and define the proper destination of the secreted sEV $[2,8]$. Endosome production can be categorized into the following three subtypes, according to each stage of development: early endosomes, late endosomes, and recycling endosomes. Early endosomes are formed by inward budding of the cell membrane, before a second inward budding of the endosomal membrane that results in the formation of late endosomes-intraluminal vesicles (ILVs). Late endosomes containing IVLs are named multi-vesicular bodies (MVBs), and the MVBs either fuse with lysosomes to degrade or follow the endocytic pathway for sEV generation. Once fusion with the plasma membrane is completed, the small membrane-enclosed vesicles are released into the extracellular matrix.

The biogenesis of sEV is affected by the following two main pathways that can induce multi-vesicular bodies (MVBs) generation: the endosomal sorting complex, required for the transport (ESCRT)-dependent pathway and ESCRT-independent pathway [9]. For the ESCRT-dependent pathway, ESCRT I and ESCRT II mediate the invagination of the late endosomal membrane, and ESCRT III will be recruited to the invaginated membrane sites. The cargo proteins are then deubiquitinated, and this stimulates the departure of the vesicle and the formation of MVBs. In the ESCRT-independent pathway, the neutral sphigomylinase2 (nSMase2) takes sphingolipids as substrates and converts sphingolipids to ceramide at the endosomal membrane. Following this, the microdomain is prepared for merging into a larger structure, which accelerates the endosomal budding and biogenesis of MVBs [10]. Moreover, sEVs that are produced by these different pathways possess different biomarkers, except CD63, which is the most common biomarker for all sEVs [11,12]. With respect to the ESCRT-dependent pathway, if endocytosis is mediated by Ras-related protein 27A/B (RAB27A/B), TSG101 is a biomarker of sEV. If the endocytosis is mediated by phospholipase D2 (PLD2) and RAB7, through the ESCRT-independent pathway, the 
biomarkers of sEV are alix, syntenin, and syndecan. As for the RAB11/35-mediated ESCRT-independent pathway, CD81, Wnt and proteolipid protein (PLP) are the preferred biomarkers.

The function of sEV in intercellular communication is determined by the interconnection between sEV surface proteins and receptors on the recipient cells that subsequently activates a variety of signaling pathways [5]. Further, sEVs arising from different cell types have different cargos that dictate and direct different biological effects. The sEVs are highly abundant in biofluids [13-15], and they have been demonstrated to be associated with immune response, viral pathogenicity, osteogenesis, odontogenesis, neuroprotection, angiogenesis, and anti-tumor functions [16]. For example, oral cancer cell-derived sEVs create a mechanism that can promote tumor progression by modifying vesicular contents and establishing a distant premetastatic niche with molecules that favor cancer cell proliferation, migration, invasion, metastasis, angiogenesis, and even drug resistance [17]. Evidence that sEVs play an important role in cell differentiation suggests that sEVs may have a potential role in tissue regeneration.

\subsection{Microvesicles}

Microvesicles (MVs) are membrane vesicles of different sizes, surrounded by a lipid layer of membrane, and they range in size from $50 \mathrm{~nm}$ to $1 \mu \mathrm{m}$. Microvesicles are generated by the outward budding of the plasma membrane, and are abundant in tissues/cells and biofluids [18]. The contents of MVs are similar to that of sEV. The MV components of note include CD40, selectins, integrins, cytoskeletal proteins, and cholesterol [19].

The biogenesis of MV involves the contraction of cytoskeletal proteins and phospholipid redistribution, contributing to a dynamic interplay in the plasma membrane and the resultant formation of microvesicles. Within the plasma membrane, the aminophospholipid translocase regulates phospholipid distribution, transferring phospholipids from one leaflet to another. Once phosphatidylserine (PS) is translocated to the leaflet of the outer membrane, the outward blebbing of the membrane and microvesicle formation is initiated. The interaction between actin and myosin causes the cytoskeletal structure contraction, which mediates membrane budding [20].

MVs have been reported to maintain tissue homeostasis during tissue regeneration, angiogenesis, anti-tumor effects, and in pathologies such as tumorigenesis, chronic inflammation, and atherosclerosis [19]. MVs that are produced by blood cells (e.g., neutrophils, macrophages, and platelets) are involved in the pro-coagulatory response [21]. MVs can be both pro-inflammatory and anti-inflammatory; this is determined by the induction or stimulation that is received by their parent cells. MVs that are produced by tumor cells enhance invasiveness and accelerate cancer progression, as well as strengthen the drug resistance of tumor cells [22]. This indicates that MVs are potential therapeutic agents for tissue regeneration; however, the function of MVs in periodontal tissue healing and regeneration requires further investigation.

\subsection{Apoptotic Bodies}

Apoptotic bodies (ApoBDs) are produced by cells undergoing apoptosis, and vary in size from $50 \mathrm{~nm}$ to $2 \mu \mathrm{m}[23,24]$. ApoBDs result from the formation of subcellular fragments when an apoptotic cell disassembles. They are comprised of molecular components from living cells and provide a rich molecular pool for recipient cells. However, ApoBDs are engulfed by macrophages and digested by phagolysosomes shortly after they are released [25]. ApoBDs and apoptosis are not related to an inflammatory reaction, the constituents in dying cells and ApoBDs are not released automatically to the environment, and anti-inflammatory cytokines are not generated during engulfing. ApoBDs have phosphatidylserine (PS) on their surfaces, to attract engulfing cells, and are considered to be specific biomarkers for ApoBDs [26]. Autoimmune diseases may be associated with defects in the clearance of ApoBDs. ApoBDs may stimulate the formation of thrombus and improve anti-cancer immunity. 
Increasing evidence suggests that ApoBDs have important immune regulatory roles, in autoimmunity, cancer, and infection [24], as well as promoting osteogenesis [27]. For example, ApoBDs that are derived from mature osteoclasts can induce osteoblast differentiation by activating the protein kinase B/phosphoinositide 3-kinases (PI3K/AKT) pathway [27]. However, knowledge of their function and role is still limited and more studies are required in this field.

\section{The Source and Characteristics of Periodontal (Dental Pulp) Cells}

Dental tissue-derived (or stem) cells have remarkable characteristics for therapeutic application, being easily accessible and a rich source of stem cells with a well-known regenerative capacity. A great variety of multipotent adult or postnatal stem cells can be retrieved from dental tissues, especially from periodontal tissue and dental pulp from extracted permanent teeth (dental pulp stem cells-DPSCs) and exfoliated deciduous teeth (SHED). A healthy periodontium consists of soft (periodontal ligament-PDL and gingiva) and hard (alveolar bone and cementum) tissue, and cells residing within the healthy periodontal tissues include periodontal ligament (stem) cells (PDLSCs), PDL and gingival fibroblasts (PDLF, GFs), or gingival stem cells (GMSCs), osteoblasts (OBs), osteoclasts (OCs), and various immune cells (Figure 2) [28,29]. Moreover, stem cells can be obtained from dental apical papilla tissues (SCAP) and dental follicles (DFSCs, or DFCs) of the developing tooth $[28,29]$. Importantly, EV that is derived from these cells can be detected within periodontal tissues and biofluid (i.e., gingival crevicular fluid) (Figure 2).

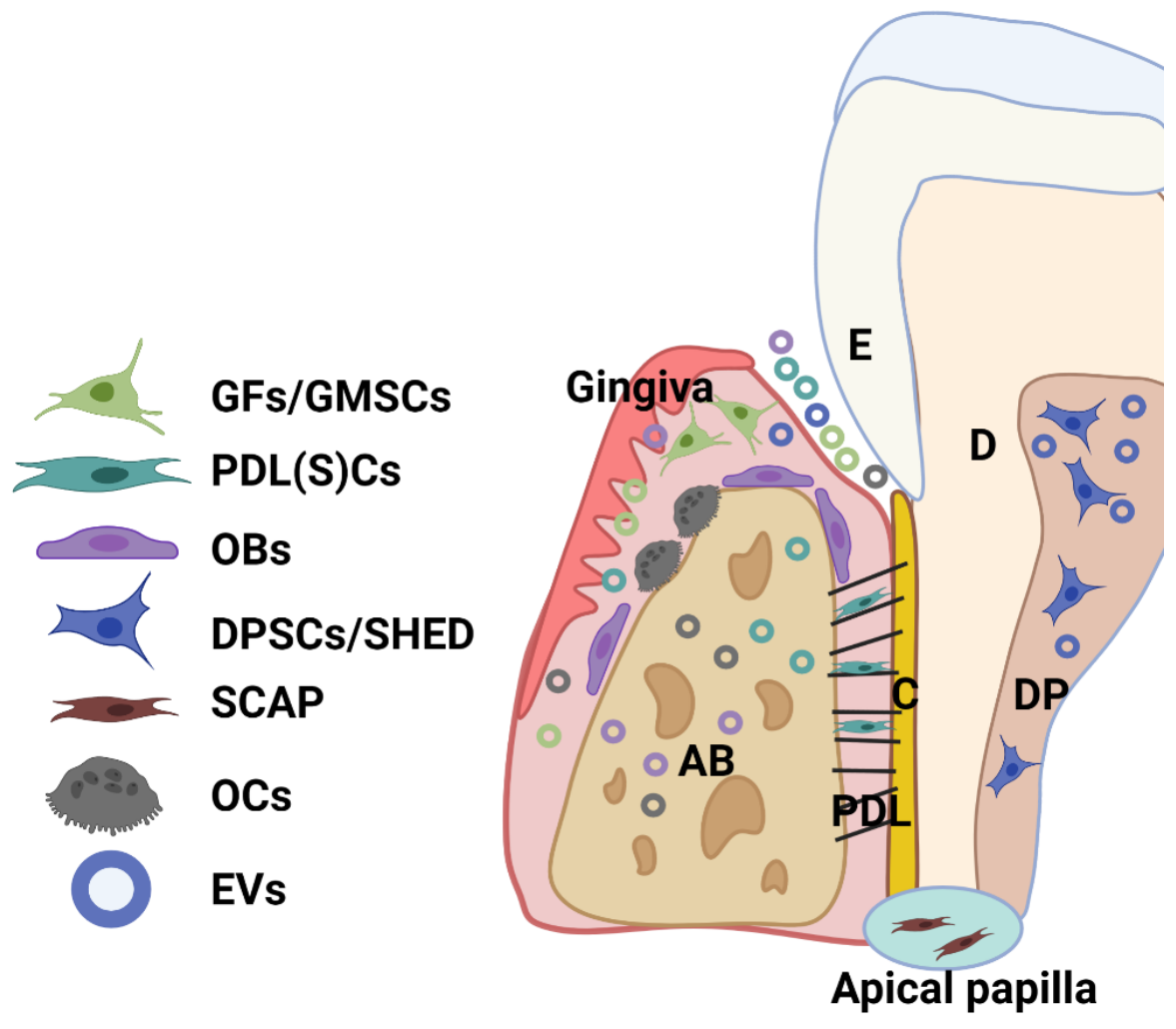

Figure 2. Schematic showing the main cell population and cell products (EVs) within a healthy periodontium. Various cells reside in the periodontium, such as periodontal ligament (stem) cells (PDLSCs), fibroblasts (GFs) and stem cells (GMSCs) from the gingiva, osteoblasts (OBs), osteoclasts (OCs), and various immune cells. AB: alveolar bone; C: cementum; D: dentin; DP: dental pulp; PDL: periodontal ligament; SHED: dental pulp cells from human exfoliated deciduous teeth (SHED); SCAP: cells from periodontal apical papilla tissues (SCAP).

Dental mesenchymal stem cells originate from the neural crest ectomesenchyme and reside in stromal niches (perivasculature and peripheral nerve-associated glia cells). The 
current consensus holds that both perivascular cells [30] and glia cells [31] are responsible for dental MSCs origin, as revealed in mouse experiments [31]. Much like bone-marrowderived MSCs that originate from mesoderm [32], dental stem cells express MSCs markers and exhibit multipotent linage regeneration (i.e., osteogenic, chondrogenic, neurogenic) and immunomodulatory capabilities. These properties make these cells suitable candidates for therapeutic application (reviewed by Chalisserry et al. in [33]) in neurological disorders, angiogenesis, dentin-pulp regeneration and periodontal regeneration. PDLSCs, GFs, DPSCs, SHED, and DFSCs have been demonstrated to promote multiple-tissue regeneration, both in vitro and in vivo [34-40]. However, cell therapy has several challenges, including high cost, insufficient cell number, and associated regulatory barriers. On the other hand, a cell-free approach, centered around cell products (i.e., EVs derived from these cells), has been proposed, and there is an emerging focus on cell-derived EVs as potential therapeutic agents to promote periodontal regeneration. The utilization of sEVs for dental tissue regeneration is emerging as a viable cell-free treatment option, with 'proof of concept' studies reported using bone marrow or adipose MSC-derived SEVs (reviewed in [41-43]); yet, periodontal or dental pulp cell sources are likely to uniquely reflect the functional complexity of the periodontium and oral cavity.

The following sections will summarize the current methods for cell-derived sEV isolation and characterization, with particular emphasis on sEVs from periodontal and dental pulp cells.

\section{Cell-Derived sEV Isolation Methods}

\subsection{General Concepts}

Although sEVs have been studied for decades, there is still no standardized protocol for their isolation. Despite the presence of recommended guidelines for EV isolation and characterization, such as the Minimal Information for Studies of Extracellular Vesicles 2014 (MISEV2014) and MISEV 2018, these guidelines are not always followed.

Prior to the isolation of $\mathrm{sEV}$, sequential centrifugation is commonly used to remove cell debris and large EVs, as follows:

i Step 1: the cell conditional media (CM) is harvested and centrifuged at $300-400 \times g$ to remove cells, and the supernatant $(\mathrm{SN})$ is collected;

ii Step 2: the SN collected in step 1 is centrifuged at $2000-3000 \times g$ to remove cells debris and apoptotic bodies. The $\mathrm{SN}$ is collected from this step;

iii Step 3: SN from step 2 is centrifuged at 10,000-20,000 $\times g$ to remove the aggregates of biopolymers, microvesicles, and the other structures with a buoyant density higher than sEVs. The SN is collected from this step;

iv Step 4: then, the following isolation methods are used to enrich the sEVs: ultracentrifugation, sucrose gradient centrifugation, size exclusion chromatography, precipitationbased isolation, immunoaffinity chromatography, and ultrafiltration.

Given the growing interest in EVs, technical standardization is critical, as many different methodologies have been utilized for isolation and analysis. The influence of these various techniques on the downstream composition and functionality of EV cargos remains unclear; accordingly, the ISEV position papers $[6,44]$ have raised the need to define 'good practices' and ultimately archive standardization. However, many researchers are not following these four steps, due to a lack of standardized protocols. Here, our review briefly introduces each isolation method, and discusses its merits and disadvantages (listed in Table 1). 
Table 1. Representative advantages and disadvantages of various EV isolation methods.

\begin{tabular}{|c|c|c|c|}
\hline Method & Time & Advantages & Disadvantage \\
\hline $\begin{array}{l}\text { Ultracentrifuge } \\
(100,000 \times-200,000 \times g \\
\text { for } 1-2 \mathrm{~h}\end{array}$ & $1.5 \mathrm{~h}$ to $10 \mathrm{~h}$ & $\begin{array}{ll}\text { - Well-known 'gold-standard' } \\
\text { method } \\
\text { - } \quad \text { Easy to access } \\
\text { - Straightforward methodology }\end{array}$ & $\begin{array}{ll}\text { - } & \text { Low recovery rate of sEV } \\
\text { - } & \text { Time consuming (normally will } \\
\text { need } 2 \text { steps of UC) } \\
\text { - } \quad \text { Impure sEV with non-EV } \\
\text { contamination and aggregates }\end{array}$ \\
\hline $\begin{array}{l}\text { Floatation-related } \\
\text { methods (sucrose } \\
\text { gradient centrifugation) }\end{array}$ & $250 \mathrm{~min}$ to 1 day & $\begin{array}{l}\text { - } \quad \text { Pure EV population } \\
\text { - } \quad \text { No protein contamination }\end{array}$ & $\begin{array}{l}\text { - Fails to separate large vesicles with } \\
\text { similar sedimentation rates }\end{array}$ \\
\hline $\begin{array}{l}\text { Size exclusion } \\
\text { chromatography (SEC) }\end{array}$ & $\begin{array}{l}\sim 30 \text { min (including } \\
\text { column washing) }\end{array}$ & $\begin{array}{ll}\text { - } & \text { Time-efficient } \\
\text { - } & \text { Pure EV product }\end{array}$ & $\begin{array}{l}\text { - } \quad \text { sEV and microvesicles cannot be } \\
\text { separated }\end{array}$ \\
\hline $\begin{array}{l}\text { Precipitation based } \\
\text { isolation (sodium } \\
\text { acetate, PEG, protamine) }\end{array}$ & $\begin{array}{l}\text { Overnight } \\
\text { incubation }\end{array}$ & $\begin{array}{l}\text { - Low-speed centrifuge }(1500 \mathrm{~g}) \\
\text { to retrieve the sEV sample } \\
\text { - } \quad \text { Straightforward method } \\
\text { Many samples can be } \\
\text { processed }\end{array}$ & $\begin{array}{l}\text { - } \quad \text { Low EV recovery } \\
\text { Co-precipitation of protein and } \\
\text { other molecules } \\
\text { - Further purification step is } \\
\text { required }\end{array}$ \\
\hline $\begin{array}{l}\text { Immunoaffinity } \\
\text { chromatography }\end{array}$ & $\sim 240 \mathrm{~min}$ & $\begin{array}{l}\text { - Very pure EV subpopulation } \\
\text { (i.e., CD9+ EV) }\end{array}$ & $\begin{array}{ll}- & \text { Low EV yield } \\
\text { - } & \text { Low scalability }\end{array}$ \\
\hline $\begin{array}{l}\text { Membrane } \\
\text { filtration/Ultrafiltration }\end{array}$ & $\sim 130 \mathrm{~min}$ & $\begin{array}{ll}\text { - } & \text { Small sample volume } \\
\text { - } & \text { Simple procedure } \\
\text { - } & \text { Higher yield than UC method }\end{array}$ & $\begin{array}{l}\text { - High contamination of non-EV } \\
\text { protein }\end{array}$ \\
\hline
\end{tabular}

\subsection{Ultracentrifuge}

Ultracentrifugation is the gold-standard method for isolating $\mathrm{sEV}$, as the equipment is relatively easy to access and the methodology is technically straightforward. The method involves an ultracentrifugation step at $100,000 \times-200,000 \times g$ to pellet sEV [45]. However, ultracentrifugation has disadvantages, in that it leads to a low recovery rate of $\mathrm{sEV}$, it is time consuming (1.5-10 h), contains non-vesicular macromolecule contamination, and results in EV aggregation.

\subsection{Floatation-Related Methods (Sucrose Gradient Centrifugation)}

Floatation-related methods distribute molecules based on the buoyant density, and the protein aggregates and SEV can be sufficiently separated. Differential gradient centrifugation (usually takes $250 \mathrm{~min}-1$ day) takes advantage of buoyant density to fractionate EVs using sucrose or idoxanol gradients [45]. The sEVs can be separated by the discontinuous gradient sucrose solution, with each layer containing the desired size of EV. Other chemical reagents (i.e., iodixanol) can also be utilized instead of sucrose, for continuous EV harvest with no layers. Non-vesicular protein contaminants are distributed at a reduced level within this method, resulting in less protein contamination. However, sucrose gradient centrifugation cannot separate large particles that have a similar sedimentation rate.

\subsection{Size Exclusion Chromatography (SEC)}

SEC can be used to isolate small sEV, based on the size of the molecules, where large particles pass through the gel earlier than the small-sized molecules. The small-sized particles are trapped in the tiny pores on the surface of the gel, while the larger molecules can bypass the gel or receive less interference from the gel [46]. This technique has been well established with commercialized SEC columns, including qEV (iZON Science), Exo-spin ${ }^{\mathrm{TM}}$ SEC columns (Cell Guidance Systems Ltd.) and Pure-EVs SEC columns (HandaBioMed, Lonza). SEC has been proposed as an effective alternative method for pure sEV isolation, 
with a key advantage being its time efficiency ( $30 \mathrm{~min}$, including $10 \mathrm{~mL}$ of column washing with PBS). However, the similarly sized sEV and microvesicles cannot be separated by SEC.

\subsection{Precipitation-Based Isolation (Sodium Acetate, PEG, Protamine)}

Precipitation-based isolation has the following two mechanisms: polymeric precipitation and neutralizing charges [47]. In polymeric precipitation, a soluble polymer, usually polyethylene glycol (PEG), is mixed with EV samples and the mixture is incubated overnight, and EVs are sedimented by low-speed centrifugation at $1500 \mathrm{~g}$. PEG precipitation enables a simple process for a large number of samples. Commercial kits, such as ExoQuick (System Biosciences), total exosome isolation reagent (Invitrogen), EXO-Prep (HansaBioMed), exosome purification kit (Norgen Biotek), and miRCURY exosome isolation kit (Exiqon), are based on this principle. For the other precipitation method, all EVs possess negative charges, so positively charged molecules (i.e., sodium acetate and protamine) are chosen for the precipitation. This method is popular due to its straightforward protocol; however, these precipitation methods lead to low sEV purity due to co-precipitation of the components from CM or biofluids, such as protein, DNA and RNA, and hence further purification is required.

\subsection{Immunoaffinity Chromatography}

The monoclonal antibodies (mAbs) against specific sEV surface proteins (i.e., CD 9) are fixed on the column, to capture a specific sEV population [48]. Once the CM passes through the column, the EVs, which express certain exosomal markers on their membrane, will be captured by the mAbs. This method leads to a very pure EV population, but low yield and scalability. This is attributed to the fact that this step needs to be repeated several times to ensure the mAbs can capture sufficient EVs ( $240 \mathrm{~min})$.

\subsection{Ultrafiltration}

Semi-permeable membranes (ranging from $3 \mathrm{kDa}$ to $100 \mathrm{kDa}$ ) are adapted for sEV fractionation within filtration-based isolation; the membrane function is determined by its pore size. However, sEVs cannot be fractionated according to their biogenesis or biomarkers, but it is normally used to concentrate sEVs. It is still an efficient way to eliminate the minimal sample volume ( 130 min) with a simple procedure, and has been proven to yield higher recovery of sEVs than ultracentrifugation [49]. However, ultrafiltration might lead to low EV protein, but a rather higher concentration of non-EV proteins (i.e., albumin).

\subsection{Current Isolation Challenge}

As mentioned previously, the current challenges of sEV isolation include time-consuming procedures, impurities, insufficient EV yield, and low scalability [50]. Although many researchers have investigated combinations of these isolation methods, an urgent demand has arisen to investigate high-yielding and time-effective isolation protocols. Currently, there is no optimal sEV isolation method; however, a combination of ultracentrifugation, SEC, and ultrafiltration has been used for the pure sEV population, which is a critical factor for downstream therapeutic applications.

\section{4. sEV Isolation and Characterization Methods for Periodontal (and Dental Pulp) Cells}

To date, there are no standardized protocols for sEV isolation and characterization. From the 33 studies that are reported in this review, we have summarized periodontal (dental pulp) cell-derived sEV isolation and characterisation methods [51-83]. Various isolation methods have been used for periodontal (dental pulp) cells sEVs, including ultracentrifugation (UC), precipitation-based methods, and ultrafiltration (Figure 3a). Regarding EV characterization, the latest MISEV 2018 guidelines [6] suggest that all EV researchers should characterize sEV from at least three different aspects, such as EV particle numbers, EV 
morphology, and EV-enriched protein markers. However, most of the current studies did not follow the MISEV guidelines, and this requires additional attention for all EV research.
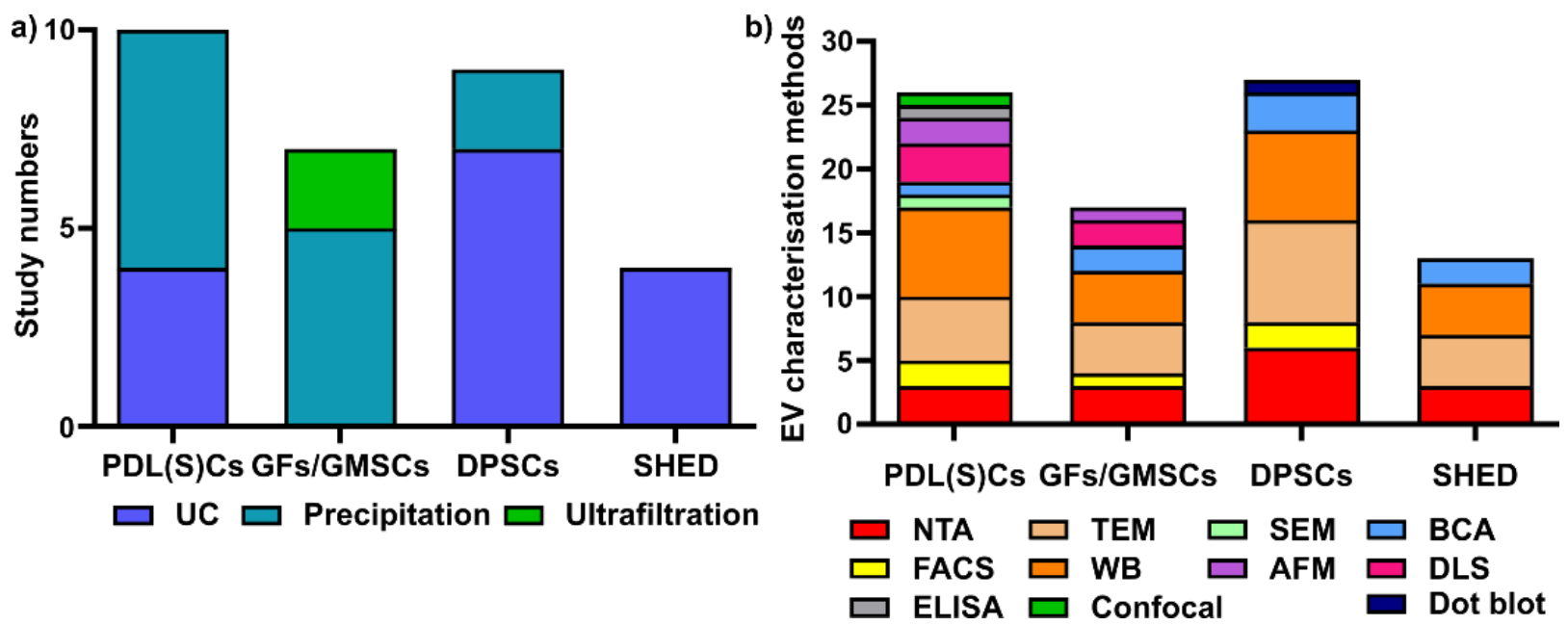

Figure 3. Various sEV isolation methods (a) and characterization methods (b) are used for periodontal (dental pulp) cells. UC: ultracentrifugation; NTA: nanoparticle tracking analysis; TEM: transmission electron microscopy; WB: Western blot; SEM: scanning electron microscopy; AFM: atomic force microscopy; BCA: bicinchoninic acid assay; DLS: dynamic light scattering; ELISA: enzyme-linked immunosorbent assay; confocal: confocal microscopy.

Different sEV isolation methods have been utilized for various cells (Figure 3a), with precipitation and ultracentrifugation methods being the two most commonly used techniques. In PDL(S)C-derived sEV isolation (10 studies), the precipitation-based method (i.e., a commercial ExoQuick kit) is the most commonly used ( $n=6,60 \%$ ), followed by ultracentrifugation $(n=4,40 \%)$. Among six studies in GFs/GMSC-derived sEVs, the precipitation-based method $(n=4,66.7 \%)$ and ultrafiltration $(n=2,33.3 \%)$ were used for GFs/GMMSCs-sEV isolation. Regarding DPSC-derived sEV, most researchers selected ultracentrifugation $(n=7,77.8 \%)$, with one study using the precipitation-based method $(n=2,22.2 \%)$. For SHED-sEVs, all of the studies $(n=4,100 \%)$ used the ultracentrifugation method to isolate sEVs from SHED.

Concerning EV characterisation [6], NTA and DLS are common methods to quantify EV particle number, size, and distribution; TEM, SEM, and AFM can be used for EV morphology and size; BCA is for EV protein quantification; and WB is to determine EVenriched protein markers. We have summarized the various EV characterisation methods for periodontal cell-derived sEVs (Figure 3b). For PDL(S)Cs-sEV (10 studies included in this review), WB is the most commonly used characterization method ( $n=7$ studies), followed by TEM $(n=5), \operatorname{NTA}(n=3)$, AFM $(n=2)$, flow cytometry $(n=2), \operatorname{SEM}(n=1)$, BCA assay $(n=1)$, ELISA $(n=1)$, and confocal microscopy $(n=1)$. In GFs/GMMSCs-sEVs, WB $(n=4)$ was utilized to detect CD9, CD63, and TSG101, as well as TEM $(n=4)$, NTA $(n=3), \operatorname{DLS}(n=2), \operatorname{BCA}$ assay $(n=2), \operatorname{AFM}(n=1)$, and FACS $(n=1)$. The characterisation of DPSC-EVs are mostly performed using WB $(n=7)$, TEM $(n=8)$, NTA $(n=6)$, BCA assay $(n=3)$, FACS $(n=2)$, and dot blot $(n=1)$. For the characterization of SHED-sEVs $(4$ studies), TEM and WB $(n=4)$ are most commonly applied; NTA $(n=3)$ and BCA $(n=2)$ were also used for OBs-sEVs.

In summary, ultracentrifugation and precipitation-based methods are the two most common methods used for periodontal (dental pulp) cells sEV isolation. WB, TEM and NTA are the most common methods for periodontal (dental pulp) cell-derived sEVs characterisation. 


\section{The Function of sEVs Derived from Periodontal (Dental Pulp) Cells}

Current studies mainly focus on small EV biogenesis and function in the periodontal regeneration field; thus, this review summarizes 33 studies [51-83] on periodontal cell-, gingival cell- and dental pulp (DPSCs and SHED) cell-derived sEV isolation, characterization, and their therapeutic role in tissue regeneration. Most of this research has focused on the function of sEVs in cell differentiation, and 11 studies investigated the cargos of sEVs (i.e., miRNA [52,53,61,63,64,72,75,81], circRNA [51,71], IncRNA [51], and EV-mRNA [67,72]) during this process.

\subsection{Periodontal Ligament Fibroblasts or Stem Cells (hPDL(S)Cs)-sEV}

A total of 10 studies investigated sEVs derived from human PDL (stem) cells or fibroblasts [51-60], and are summarized in Table 2. Eight studies isolated sEV from hPDLSCs [51-53,55,56,58-60], with one study each using sEVs from a human PDL fibroblast (hPDLFs) cell line [54] and hPDLCs [57]. Three of these studies investigated hPDLCs sEV function in vivo, using animal models $[56,59,60]$.

According to the latest MISEV 2018 guidelines [6], it is critical to consider several factors influencing the collection of $\mathrm{EV}$, including characteristics of primary cell source (donor health status, age, gender), primary cell passage number, confluence at harvest, culture volume, media change frequency, CM harvesting conditions, as well as all culture media composition and preparation details. Thus, our review includes detailed donor information for primary cells (if mentioned), the cell culture condition prior to CM collection, and detailed SEV isolation protocols. This will allow future EV researchers to select appropriate protocols for $\mathrm{CM}$ harvesting and $\mathrm{sEV}$ isolation.

Donor age was disclosed in only two studies (18-30 [51] and 18-21 years old [55]), while there is no clear information in the other studies [52-54,56-60]. The cells at passages 2-3 were used in five studies [51-53,56,59], passage 3-7 in one study [54], with no passage information provided in the remaining studies $[55,57,58,60]$. Since fetal calf serum (FBS or FCS) contains a large amount of EV, it is crucial to state how cells are cultured before CM harvesting. Currently, either EV-depleted FBS or FBS starvation is used before CM harvest for PDLCs-sEV isolation; from the 10 studies that were reviewed, 5 did not state how the cells were cultured before CM collection [53,56,58-60], 4 studies used EV-depleted FBS $[52,54,55,57]$, and one study used FBS starvation [51]. While it is of considerable importance to clearly articulate the cell source, passage number, and CM harvest condition, this is something that is currently under-reported in many studies.

The following three aspects of hDPL(S)Cs-sEV analysis were evaluated in the 10 studies that have been included in this review: (1) EV size, (2) EV content (protein, RNA, etc.), and (3) EV function in cell differentiation in vitro and in vivo. Regarding the size of $\mathrm{hPDL}(\mathrm{S}) \mathrm{Cs}-\mathrm{sEV}$, three studies did not characterize the sEV size $[52,53,60]$. There is a large deviation for the reported EV size: $<200 \mathrm{~nm}$ in five studies [ $51,54,55,57,58]$, two populations $(90 \pm 20 \mathrm{~nm}$ and $1200 \pm 400 \mathrm{~nm}$ ) in one study [59], and 100-710 nm in one study [56]. It is noted that two studies engineered the hPDLCs-EV using polyethyleneimine (PEI, yielding PEI-EV) $[56,59]$. The following two factors may contribute to this deviation: the EV isolation method (UC or precipitation methods), and the EV size characterization methods (TEM, or DLS, or NTA). We will define EV size $<200 \mathrm{~nm}$ as sEV, and unclear EV size as EV. 
Table 2. The isolation, characterization, and function of PDL(S)C-derived EVs.

\begin{tabular}{|c|c|c|c|c|}
\hline Reference & Cell Source & EV Isolation & EV Characterization & Key Findings \\
\hline Xie et al., 2021 [51] & $\begin{array}{l}\text { - } \quad \text { hPDLSCs } \\
\text { Donor: Healthy patients aged } \\
\text { 18-30 years old, with no } \\
\text { system diseases, underwent } \\
\text { impacted third molar or } \\
\text { orthodontic extractions } \\
\text { Passage } 3\end{array}$ & $\begin{array}{l}\text { - } \quad \text { FBS starvation for } 48 \mathrm{~h} \\
3000 \mathrm{~g} \text { for } 20 \mathrm{~min} ; 16,500 \mathrm{~g} \text { for } \\
20 \mathrm{~min} ; 0.2 \mu \mathrm{m} \text { filter; } \\
\text { ultracentrifuge at } 100,000 \times g \\
\text { for } 70 \text { min } \\
\text { - Centrifuge temperature } \\
\text { unclear } \\
\text { Exosomes from hPDLSCs } \\
\text { before (EX0) and after } \\
\text { osteogenic induction for } 5 \\
\text { (EX5) and 7 (EX7) days }\end{array}$ & $\begin{array}{ll}\text { - } & \text { NTA } \\
\text { - } & \text { Flow cytometry } \\
\text { - } & \text { TEM } \\
& \text { WB (CD63 and CD81) }\end{array}$ & $\begin{array}{l}\text { - The size of sEV ranged from } 20 \text { to } 100 \mathrm{~nm} \text {. } \\
\text { 69-557 sEV-circRNAs and } 2907-11,581 \text { exosomal } \\
\text { lncRNAs were found in EX0, EX5 and EX7 by } \\
\text { RNA sequencing. } \\
\text { - Within hPDLSCs-exosomes, compared with } \\
\text { EX0, } 3 \text { circRNAs and } 2 \text { lncRNAs were } \\
\text { upregulated and } 39 \text { circRNAs and } 5 \text { lncRNAs } \\
\text { downregulated in EX5 and EX7. } \\
\text { Exosomal circRNAs may function as competing } \\
\text { endogenous RNAs through a } \\
\text { circRNA-miRNA-mRNA network via TGF- } \beta \\
\text { pathway, MAPK pathway, mTOR pathway and } \\
\text { FoxO signaling pathways during hPDLSCs } \\
\text { osteogenic differentiation in vitro. }\end{array}$ \\
\hline Zhang et al., 2020 [52] & $\begin{array}{ll}\text { - } & \text { hPDLSCs } \\
\text { Donors: Periodontal ligaments } \\
\text { from premolars of healthy and } \\
\text { periodontitis patients } \\
\text { - } \\
\text { - } \quad \text { Pase unclear } \\
\text { Passage } 2-5\end{array}$ & $\begin{array}{l}\text { - } \quad \text { hPDLSCs were cultured with a } \\
\text { vesicle-free medium. } \\
\text { Centrifuge for } 10 \mathrm{~min} \text { at } 500 \times \\
g, 30 \text { min at } 16,000 \times g ; \\
\text { ultracentrifugation for } 70 \mathrm{~min} \\
\text { at } 150,000 \times g\end{array}$ & $\begin{array}{ll}\text { - } & \text { Flow cytometry } \\
\text { - } & \text { TEM } \\
\text { - } & \text { WB (TSG101 and } \\
\text { CD63) } \\
\text { - SEM }\end{array}$ & $\begin{array}{l}\text { EV size was not mentioned. } \\
\text { - When co-cultured with TNF-alpha, the } \\
\text { angiogenesis of HUVECs was promoted by } \\
\text { hPDLSCs exosomes. } \\
\text { The angiogenesis of HUVECs was } \\
\text { downregulated when the secretion of exosomes } \\
\text { was blocked. } \\
\text { Inflammation influenced pro- angiogenesis of } \\
\text { hPDLSCs via regulating the exosome-mediated } \\
\text { transfer of VEGFA targeted by miR-17-5p. }\end{array}$ \\
\hline Chiricosta et al., 2020 [53] & $\begin{array}{l}\text { - } \quad \text { hPDLSCs } \\
\text { Donor: Five healthy patients } \\
\text { from tooth removal for } \\
\text { orthodontic purposes } \\
\text { - Passage } 2\end{array}$ & $\begin{array}{l}\text { - } \quad \text { Conditioned medium of } \\
\text { hPDLSCs at (CM; } 10 \mathrm{~mL}) \text { after } \\
48 \mathrm{~h} \text { of incubation. } \\
15 \mathrm{~min} \text { at } 3000 \times g ; \text { mixed with } \\
\text { ExoQuick TC reagent at } 4{ }^{\circ} \mathrm{C} \\
\text { overnight } 1500 \times g \text { for } 30 \mathrm{~min} .\end{array}$ & $\begin{array}{l}\text { - } \quad \text { No EV } \\
\text { characterization } \\
\text { performed before } \\
\text { RNA sequencing }\end{array}$ & $\begin{array}{l}\text { - } \quad \text { EVs size was not mentioned } \\
\text { The EV derived from hPDLSCs contain several } \\
\text { non-coding RNAs, especially the following five } \\
\text { miRNAs: miR24-2, miR142, miR296, miR335, and } \\
\text { miR490. The target genes of these miRNAs are } \\
\text { involved in Ras protein signal transduction and } \\
\text { actin/microtubule cytoskeleton organization. }\end{array}$ \\
\hline
\end{tabular}


Table 2. Cont.

\begin{tabular}{|c|c|c|c|c|}
\hline Reference & Cell Source & EV Isolation & EV Characterization & Key Findings \\
\hline Zhao et al., 2019 [54] & $\begin{array}{l}\text { - Human periodontal ligament } \\
\text { - } \quad \text { MGroblasts (hPDLFs) cell line } \\
\text { - } \quad \text { Passages 3-7 }\end{array}$ & $\begin{array}{l}\text { P. gingivalis LPS-treated } \\
\text { hPDLFs for } 4 \mathrm{~h} \text { and cultured } \\
\text { with exosome-depleted } \\
\text { FBS } / 1 \% \text { PS for another } 24 \mathrm{~h} \text {. } \\
1000 \times g \text { for } 10 \text { min and } \\
10,000 \times g \text { for } 15 \text { min, } 0.22 \mu \mathrm{m} \\
\text { Millipore filter; concentrated } \\
\mathrm{CM}(3-5 \mathrm{~mL}) \text { using a } 100 \mathrm{kDa} \\
\text { ultracentrifuge filter at } 5000 \times \\
g \text { in for } 30 \text { min; ExoQuick-TC } \\
\text { reagent was added and } \\
\text { incubated with CM overnight, } \\
\text { centrifuge the mixture at } \\
1500 \times g \text { for } 30 \text { min }\end{array}$ & $\begin{array}{ll}- & \text { BCA } \\
- & \text { TEM } \\
- & \text { Dynamic light } \\
& \text { scattering (DLS) } \\
\text { - } & \text { WB (CD9, CD63, } \\
& \text { TSG101) }\end{array}$ & $\begin{array}{l}\text { Exosomes size: } 70-100 \mathrm{~nm} \text {, peaked at } 84 \mathrm{~nm} \text {. } \\
\text { Exosome-enriched protein and total exosomal } \\
\text { protein levels were higher in the LPS-treated } \\
\text { hPDLFs than those in non-LPS-treated hPDLFs. } \\
\text { Upregulated IL-6, TNF- } \alpha \text { and inhibited } \\
\text { expression ALP, collagen-I, RUNX2, and OPG } \\
\text { were found in MG-63 OBs after uptaking the } \\
\text { exosomes derived from LPS-treated hPDLFs. }\end{array}$ \\
\hline $\begin{array}{l}\text { Čebatariūn-ienè et al., } 2019 \\
\text { [55] }\end{array}$ & $\begin{array}{l}\text { hPDLSCs grew in a bioreactor } \\
\text { on gelatin-coated microcarriers } \\
\text { Donor: healthy periodontal } \\
\text { tissues of two Caucasian } \\
\text { females (18 and } 21 \text { years old) } \\
\text { using explant outgrowth } \\
\text { method }\end{array}$ & $\begin{array}{l}\text { - } \\
\text { Pupernatants (SN) from } \\
\text { supplemented with } 10 \% \text { of } \\
\text { EV-depleted FCS every } 72 \mathrm{~h} \\
\text { - } \quad \text { All centrifugation steps were } \\
\text { performed at } 4{ }^{\circ} \mathrm{C} \\
\text { - } 300 \mathrm{~g} \text { for } 10 \mathrm{~min}, 2000 \mathrm{~g} \text { for } 10 \\
\text { min; } 20,000 \mathrm{~g} \text { for } 30 \mathrm{~min} \text {; then } \\
\text { ultracentrifuged at } 100,000 \times g \\
\text { for } 70 \text { min. } \\
\text { The pellets were washed in } 40 \\
\text { mL PBS and ultracentrifuged } \\
\text { again at } 100,000 \times g \text { for } 70 \mathrm{~min}\end{array}$ & $\begin{array}{ll}- & \text { TEM } \\
\text { - } & \text { NTA } \\
\text { - } & \text { WB (CD63, MFG-E8) }\end{array}$ & $\begin{array}{l}\text { - The size of sEV derived from microcarrier cell } \\
\text { cultures of PDLSCs: } 112-182 \mathrm{~nm} \text {. } \\
\text { - } \quad \text { hPDLSCs-sEV suppressed basal and } \\
\text { LPS-induced activity of NF-kB in PDLSCs. } \\
\text { Combined treatment with EV and anti-TLR4 } \\
\text { antibody attenuated the inhibitory effect on the } \\
\text { NF-kB activity } \\
\text { - Uptake of hPDLSCs-sEV in hPDLSC-activated } \\
\text { phosphorylation of Akt and GSK3ß (Ser 9) } \\
\text { indicating that PI3K/Akt signaling pathway may } \\
\text { act as a suppressor of NF-kB activity } \\
\text { EVs did not significantly affect osteogenic } \\
\text { mineralization of hPDLSCs cultures, but EV } \\
\text { significantly increased expression of ALP, OPN, } \\
\text { BSP, and CP23 gene expression, but } \\
\text { downregulated BMP2 expression on the } 10 \text { days } \\
\text { of osteogenic differentiation. }\end{array}$ \\
\hline
\end{tabular}


Table 2. Cont.

\begin{tabular}{|c|c|c|c|c|}
\hline Reference & Cell Source & EV Isolation & EV Characterization & Key Findings \\
\hline $\begin{array}{l}\text { Pizzicannel-la et al., } 2019 \\
\text { [56] }\end{array}$ & $\begin{array}{l}\text { - } \quad \text { hPDLSCs } \\
\text { Donor: Five healthy } \\
\text { participants undergoing teeth } \\
\text { removal for orthodontic } \\
\text { purpose; age unclear } \\
\text { Passage 2 }\end{array}$ & $\begin{array}{l}\text { The CM from } 15 \times 10^{3} / \mathrm{cm}^{2} \\
\text { hPDLSCs was centrifuged at } \\
3000 \times g \text { for } 15 \mathrm{~min} ; 2 \mathrm{~mL} \text { of } \\
\text { ExoQuick TC was added to } 10 \\
\text { mL of CM; incubated } \\
\text { overnight at } 4^{\circ} \mathrm{C} \text { without } \\
\text { rotation, centrifuge at } 1500 \times g \\
\text { for } 30 \text { min, resuspend with } 200 \\
\mu \mathrm{L} \text { PBS } \\
\text { EVs were coated with } \\
\text { branched polyethylenimine } \\
\text { (PEI, yielding PEI-EV) }\end{array}$ & $\begin{array}{ll}- & \text { DLS } \\
\bullet & \text { AFM }\end{array}$ & $\begin{array}{l}\text { - hPDLSCs-EV: 100-710 nm; engineered PEI-EV: } \\
\text { 1050-7700 nm by DLS. } \\
\text { In vitro: increased expression of osteogenic } \\
\text { markers (RUNX2, COL1A1, BMP2/4, VEGFA } \\
\text { and VEGFR2) in hPDLSCs cultured in a collagen } \\
\text { membrane with EVs and PEI-EVs, as well as } \\
\text { increased protein levels of VEGF and VEGFR2. } \\
\text { in vivo: EV and PEI-EV groups increased VEGF } \\
\text { and VEGFR2 protein expression at } 6 \text { weeks post } \\
\text { transplanting into a rat calvarial defect, as well as } \\
\text { enhanced vascular and bone formation. While } \\
\text { PEI-EV showed better bone and vascularization } \\
\text { than that of the EV group. }\end{array}$ \\
\hline
\end{tabular}

- $\quad$ Exosome-depleted FBS was prepared using the FBS exosome depletion kit (Norgen, Thorold, ON, Canada)

- The PureExo R exosome isolation kit (101Bio, Mountain View) was used for exosome isolation.

- $\quad$ Human PDL cells (hPDLCs) were prepared from the PDL of fully erupted lower third molar teeth

Wang et al., 2019 [57]

- A mouse macrophage-like cell line (J774.1)

- Human monocyte-like cell line THP-1
- SN was centrifuged at $3000 \times g$ for $15 \mathrm{~min}$; $2 \mathrm{~mL}$ of $\mathrm{SN}$ mixed with a solution of PureExo isolation kit and incubated at $4{ }^{\circ} \mathrm{C}$ for $30 \mathrm{~min}$, centrifuged at $5000 \times g$ for $3 \mathrm{~min}$, air-dried, re-suspension in $100 \mu \mathrm{L} \mathrm{PBS}$; centrifuge for $5 \mathrm{~min}$ at $5000 \times g$;

- Processed on a PureExo column, centrifuged at $1000 \times g$ for $5 \mathrm{~min}$.
- TEM

- WB (CD9)

- $\quad$ ELISA using PS

CaptureTM exosome

ELISA kit for CD63
- $\quad$ D: 30 and $100 \mathrm{~nm}$ (average $50 \mathrm{~nm}$ ).

- Cyclic stretch (CS) exposed PDL cells generated 30 times more exosomes compared to non-CS treated normal PDL cells at $24 \mathrm{~h}$

- CS hPDLC exosomes inhibited IL-1 $\beta$ production in LPS/nigericin-stimulated J774.1 macrophages and the nuclear translocation of NF-kB as well as NF-kB p65 DNA-binding activity in

LPS-stimulated macrophages, suggesting that exosomes suppress IL- $1 \beta$ production by inhibiting the NF-kB signaling pathway. 
Table 2. Cont.

\section{Reference} Cell Sourc

- $\quad$ hPDLSCs and THP-1 cells lines

Kang et al., 2018 [58]
- The passage not mentioned for hPDLSCs

\section{EV Isolation}

\section{EV Characterization}

- hPDLSCs were treated with $1 \mu \mathrm{g} / \mathrm{mL}$ of LPS for $1 \mathrm{~h}$ and $\mathrm{CM}$ was collected after $24 \mathrm{~h}$ of incubation and filtered using a $0.22 \mu \mathrm{m}$ filter.

- $\quad$ CM was centrifuged at $2000 \times$ $g$ for 10 min at $4{ }^{\circ} \mathrm{C}$ and filtration through a $0.22 \mu \mathrm{m}$

filter; ultracentrifuged at $100,000 \times g$ for $60 \mathrm{~min}$ at $4{ }^{\circ} \mathrm{C}$.
- NTA

WB (CD81 and CD63)

\section{Key Findings}

- $\quad$ The median sEV particle sizes were $151.3 \mathrm{~nm}$ and $146.9 \mathrm{~nm}$ for the EVs from control hPDLSCs and LPS-preconditioned hPDLSCs.

- $\quad$ sEV particle number was significantly decreased in the sEV from LPS-preconditioned PDLSCs compared to those from the control hPDLSCs.

- $\quad$ sEV from LPS-preconditioned hPDLSCs induced M1 polarization in THP-1 cells, with increased mRNA expression of IL- 6 and TNF- $\alpha$, and TNF- $\alpha$ protein. The M1 polarization was abolished by DNase I treatment of sEV.

- $\quad$ DLS analysis showed that hPDLSCs-EV had two populations of vesicles, with an average diameter of $90 \pm 20 \mathrm{~nm}$ and $1200 \pm 400 \mathrm{~nm}$.

- After $48 \mathrm{~h}$ of incubation, the conditioned medium (CM; 10

$\mathrm{mL}$ ) was collected from

- hPDLSCs culturing on collagen membranes (Evolution-Evo).

Diomede et al., 2018 [59]

- Donor: Five participants, either patient for orthodontic purposes or healthy volunteers. Unclear age.

- $\quad$ Passage 2
hPDLSCs.

- $\mathrm{CM}$ was centrifuged at $3000 \times$ $g$ for $15 \mathrm{~min} ; 2 \mathrm{~mL}$ ExoQuick TC was added to $10 \mathrm{~mL} \mathrm{CM}$; incubated overnight at $4{ }^{\circ} \mathrm{C}$ without rotation, centrifuge at $1500 \times g$ for $30 \mathrm{~min}$

- $\quad$ EVs were engineered by noncovalently coating EVs with PEI
- DLS

- $\mathrm{AFM}$

hPDLSCs-PEI-EV size: $250 \pm 50 \mathrm{~nm}$ and $3600 \pm$ $500 \mathrm{~nm}$ for two populations.

- $\quad$ Evo enriched with EV and PEI-EV showed high biocompatibility and osteogenic properties both in vitro and in vivo.

- $\quad$ PEI-EV promoted the expression of osteogenic genes, such as TGF $\beta 1$, MMP8, TUFT1, TFIP11, BMP2, and BMP4 after 6 weeks of in vitro osteogenic differentiation in hPDLSCs.

- $\quad$ PEI-EV group led to an in vivo organized extracellular matrix showing mineralization areas and blood-vessel formation, with upregulated BMP2/4 in collagen membrane enriched with PEI-EV and hPDLSCs after 6 weeks in a rat calvarial defect. 
Table 2. Cont.

\section{Reference}

Cell Source
EV Isolation
EV Characterization

\section{Key Findings}

- $\quad$ EV size was not mentioned.

- After intravenous administration of

hPDLSCs-EV into EAE rats, pro-inflammatory cytokines IL-17, IFN- $\gamma$, IL-1 $\beta$, IL-6, and TNF- $\alpha$ were reduced, while the anti-inflammatory cytokine, IL-10, was upregulated. Meanwhile, apoptosis-related STAT1, p53, Caspase 3, and Bax expressions were attenuated.

- $\mathrm{CM}$ was centrifuged at $3000 \times$ $1500 \times g$ for $30 \mathrm{~min}$. $g$ for 15 min; 2 mL ExoQuick TC was added to $10 \mathrm{~mL} \mathrm{CM}$ recovered from hPDLSCs, incubated overnight at $4{ }^{\circ} \mathrm{C}$ without rotation, centrifuge at

- Confocal image of CD 63 using fluorescent lipid probes rom human premolar teet healthy and

relapsing-remitting multiple sclerosis (RR-MS) patients
- No appropriate characterisation
- $\quad$ hPDLSCs-EV from MS patients and healthy

donors block experimental autoimmune encephalomyelitis (EAE), a mouse model of MS by inducing anti-inflammatory and immunosuppressive effects in the spinal cord and spleen, and reverse disease progression by restoring tissue integrity via remyelination in the spinal cord.

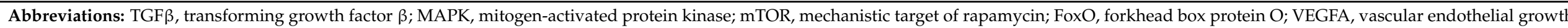

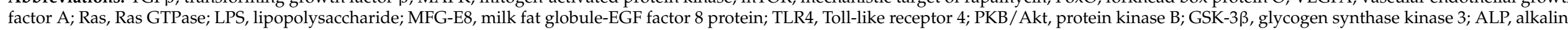

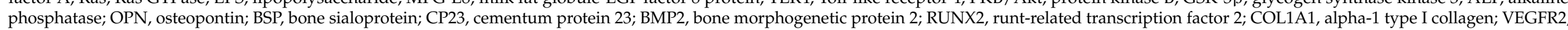

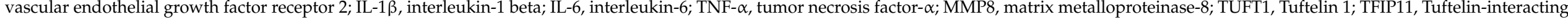
protein 11; IL-17, interleukin-17; IFN- $\gamma$, interferon- $\gamma$; IL-10, interleukin-10; STAT1, signal transducer and activator of transcription 1; Bax, Bcl-2-associated X protein. 
Regarding the EV content, it seems that hPDLCs-EV contain miRNAs $[52,53]$ and circular RNAs [51] that may alter the recipient cells functions. RNA sequencing of hPDLSCs-EV (where EV size was unclear) revealed that hPDLSCs-EV contains 955 non-coding transcripts, with five representative miRNAs, including MIR24-2, MIR142, MIR296, MIR335, and MIR490 [53]. The hDPLSCs-EV-miR-17-5p can regulate the angiogenesis of human umbilical vein endothelial cells (HUVECs) during inflammatory stimulation by TNF- $\alpha$ [52]. Furthermore, circular RNA and long non-coding RNAs (lncRNAs) were also found in the sEV from hPDLSCs, after five and seven days of osteogenic differentiation, with 69-557 circRNAs and 2907-11,581 lncRNAs detected by RNA sequencing. Compared with the sEV from hPDLSCs before osteoinduction, $3 \mathrm{sEV-circRNAs}$ and $2 \mathrm{sEV-lncRNAs} \mathrm{were} \mathrm{upregu-}$ lated, while $39 \mathrm{sEV-circRNAs}$ and $5 \mathrm{sEV-lncRNAs}$ were downregulated after 5 and 7 days of osteoinduction. RT-qPCR validation showed that three sEV-circRNAs (hsa_circ_0087960, hsa_circ_0000437, and hsa_circ_0000448) were upregulated after osteogenic differentiation, while one was downregulated (hsa_circ_0000448). However, three selected lncRNAs (small nucleolar RNA host gene5-SNHG5, LOC100130992, and ATP6VB1-AS1) showed no difference between the groups [51].

There is increasing evidence demonstrating that $\mathrm{hPDL}(\mathrm{S}) \mathrm{Cs}-\mathrm{EV}$ can modulate in vitro angiogenesis (in HUVECs [52]), osteogenesis (in MG-63 OBs [54] and hPDLSCs [55,56,59]), anti-inflammation (in LPS-treated hPDLSCs $[55,60]$ and J774.1 macrophages [57]), and immunoregulation (induced M1 polarization in THP-1 cells [58]) via modulating the TGF-beta pathway, MAPK pathway, mTOR pathway and FoxO signaling pathways [51], and PI3K/Akt signaling [55] and NF-kB signaling pathways [57]. The in vivo function of hPDL(S)Cs-EV was explored, either in rat calvaria defect [56,59] or intravenous administration in mouse multiple sclerosis disease [60] models. Pizzicannel-la et al. [56] created a calvarial defect, with a diameter of $4 \mathrm{~mm}$ and a height of $0.25 \mathrm{~mm}$ in male Wistar rats (300-350 g; $n=4$ for each group). The hPDLSCs-EV and hPDLSCs-PEI-EV were loaded on collagen membranes and transplanted into the rat calvaria defect for 6 weeks, leading to enhanced bone and vascularization compared to the no-EV groups, with the PEI-EV group inducing better osteogenesis and vascularization compared to the EV group. Diomede et al. [59] revealed similar results, showing that hPDLSCs-PEI-EV leads to increased blood vessel formation after 6 weeks of the transplantation of hPDLSCs-EV- and hPDLSCs-PEIEV-loaded collagen membranes into a rat calvarial defect. Rajan et al. [60] established a mouse model of MS disease, and intravenous administration of hPDLSCs-EVs decreased apoptosis and inflammation in the diseased mice.

In summary, the size of hPDL(S)Cs-EV ranges from $20 \mathrm{~nm}$ to $1600 \mathrm{~nm}$ when using different EV isolation methods, with under-reporting of sufficient detail about the cell source and cell culture conditions before CM collection. The hPDL(S)Cs-EV contains miRNAs, circRNAs, and lncRNAs, and they modulate the angiogenesis, osteogenesis, and inflammation of recipient cells, through TGF- $\beta$, MAPK, mTOR and FoxO pathways [51], and PI3K/Akt [55] and NF-kB signaling pathway [57]. However, none of the three in vivo studies $[56,59,60]$ used either a periodontal defect or a periodontitis animal model.

\subsection{Human Gingival Fibroblasts ( $h G F s$ ) $-s E V$}

Table 3 summarizes seven studies [61-67]) of EV from fibroblasts (hGFs [62,63] or MSCs (hGMSCs $[61,64-67]$ ) from human gingiva tissues. There are two studies that investigated the in vivo role of hGMSCs-EV using animal models $[66,67]$. The cells from either 20-to-40-year-old donors [66] or unclear age human donors [62-65,67] were used at passage 2 [64], passage 4-6 [62], <6 passage [66], or unclear [63,65,67]. EV-depleted FBS [61,63,66], FBS starvation [65], and unclear cell culture conditions [62,64,67] were applied in the studies before CM collection for EV isolation. The size of hGFs/hGMSCs-EV varied from different studies, as follows: <200 $\mathrm{nm}[61-63,66], 50-500 \mathrm{~nm}$ [65], unclear size [64], and a combination of two populations $(93 \pm 24 \mathrm{~nm}$ and $1200 \pm 400 \mathrm{~nm})$ [67]. Engineered hGMSCs-PEI-EV had the following two populations: $250 \pm 50 \mathrm{~nm}$ and $3600 \pm 500 \mathrm{~nm}$ [67]. 
Table 3. The isolation, characterization, and function of EV from hGFs or hGSMCs.

\begin{tabular}{|c|c|c|c|}
\hline Reference & Cell Source & EV Isolation & EV Characterization \\
\hline $\begin{array}{l}\text { Nakao et al., } 2021 \\
\text { [61] }\end{array}$ & $\begin{array}{ll}\text { - } & \text { Human gingival mesenchymal } \\
\text { stem cells (hGMSCs) } \\
\text { - } \quad \text { Donor details are unclear } \\
\text { - } \quad \text { Passage 4-6 }\end{array}$ & $\begin{array}{l}\text { - } \quad \text { CM was collected after } 48 \mathrm{~h} \text { in } \\
\text { FBS-free media and centrifuged at } \\
10,000 \times g \text { for } 30 \text { min. } \\
\text { hGMSCs exosomes were isolated } \\
\text { using MagCapture TM exosome } \\
\text { isolation kit PS (FUJIFILM Wako). }\end{array}$ & $\begin{array}{ll}- & \text { TEM } \\
\text { - } & \text { NTA } \\
\text { WB (CD9, CD63 and } \\
\text { CD81) }\end{array}$ \\
\hline
\end{tabular}

- $\quad$ Mode of sEVs: $109 \pm 3.1 \mathrm{~nm}$ and $104 \pm 1.8 \mathrm{~nm}$ for hGMSCs-sEVs and TNF- $\alpha$ pre-treated hGMSCs-derived sEVs.

- In vitro: TNF- $\alpha$ stimulation increased the number of hGMSCs-sEVs and exosomal CD73, as well as induced anti-inflammatory M2 macrophage polarization. The hGMSCs-sEVs-miR-1260b can target Wnt5a-mediated RANKL expression.

- in vivo: in a ligature-induced mice periodontitis model, a local injection of GMSC-derived

exosomes significantly reduced periodontal bone resorption.

- hGFs

- Donor: Five normal gingival tissues $(n)$ and 1 idiopathic gingival fibromatosis (IGF)

Yin et al., 2020 [62] gingival tissues

- $\quad$ Passage 4-6
- ExoQuick TC (no detailed isolation protocol)
BCA assay
- TEM
- $\quad$ FACS (CD63 and CD81)

- D: 50-200 nm

- IGF-GFs-Exo increased cell proliferation of normal hGFs at $24 \mathrm{~h}$ and $48 \mathrm{~h}$ by MTS assay.

- The expression of Ki67, PCNA, Bcl-2, and Bax were enhanced after $24 \mathrm{~h}$ treated with IGF-GFs-Exo. After $48 \mathrm{~h}$, the level of $P C N A, B c l-2$ and Bax was significantly downregulated, while the expression of Ki67 was not varied significantly.

- hGFs

- Donor: Fresh human gingiva from donors with wisdom tooth extraction

Zhuang et al., 2020

- hBMSCs

[63]

- Donor: Fresh human bone marrow from the iliac bone of jaw cysts during the reconstruction of bone defects with hydroxyapatite powder and bone marrow after surgery curettage

- $\quad$ Exosome-depleted medium was obtained after 25,000 r.p.m. ultracentrifugation for $90 \mathrm{~min}$. Then, $10 \mathrm{~mL}$ of $\mathrm{CM}$ was mixed with ExoQuick exosome precipitation solution and refrigerated overnight.

- TEM

- CM was centrifuged at 1500 r.p.m. for $30 \mathrm{~min}$ at $4{ }^{\circ} \mathrm{C}$ and then at 3000 r.p.m. for $5 \mathrm{~min}$.
- TEM of EV diameter: 50 to $200 \mathrm{~nm}$.

- Irradiation-activated hGFs-exosome inhibited osteogenic differentiation of hBMSCs for 7 days, with reduced $A L P, C O L 1$ and RUNX2 gene expression via an exosomal miR-23a/CXCL12 axis. 
Table 3. Cont.

\begin{tabular}{|c|c|c|c|c|}
\hline Reference & Cell Source & EV Isolation & EV Characterization & Key Findings \\
\hline $\begin{array}{l}\text { Silvestro et al., } 2020 \\
\text { [64] }\end{array}$ & $\begin{array}{l}\text { - } \quad \text { hGMSCs } \\
\text { Donor: six healthy adult } \\
\text { volunteers with no gingival } \\
\text { inflammation during teeth } \\
\text { removal for orthodontic } \\
\text { purpose } \\
\text { - Passage } 2\end{array}$ & $\begin{array}{l}\text { The conditioned medium (CM; } 10 \\
\mathrm{~mL}) \text { after } 48 \mathrm{~h} \text { of incubation were } \\
\text { collected from hGMSCs at passage } 2 \text {. } \\
\text { The CM was centrifuged at } 3000 \times g \\
\text { for } 15 \mathrm{~min} ; 2 \mathrm{~mL} \text { ExoQuick TC was } \\
\text { added to } 10 \mathrm{~mL} \text { of } \mathrm{CM} \text { and } \\
\text { incubated overnight at } 4{ }^{\circ} \mathrm{C} \text { without } \\
\text { rotation; one centrifugation step was } \\
\text { performed at } 1500 \times g \text { for } 30 \text { min to } \\
\text { sediment the EVs }\end{array}$ & $\begin{array}{l}\text { - } \quad \text { No EV } \\
\text { characterization }\end{array}$ & $\begin{array}{l}\text { - The size of EV was not mentioned. } \\
\text { RNA sequencing analysis showed that } 15,380 \\
\text { genes were identified in GMSCs-EVs. There were } \\
\text { 1067, 886, 808, 768, 562, and } 541 \text { protein-coding } \\
\text { genes for hydrolase, enzyme modulators, the } \\
\text { transcription factor, transferase, the receptor and } \\
\text { the transporter, respectively. There were } 1155 \\
\text { non-coding RNA genes for anti-sense RNAs, } \\
\text { lncRNAs and miRNAs (miR1302 family, miR451 } \\
\text { family, miR24 family, miR219 family and miR194 } \\
\text { family). } \\
\text { hGMSCs-EV also contain mRNAs for proteins of } \\
\text { the interleukins, TGF-, BMPs, GDFs, Wnt, VEGF, } \\
\text { FGF, and neurotrophins are critical for basic or } \\
\text { neuronal, bone or vascular development. }\end{array}$ \\
\hline Coccè et al., 2019 [65] & $\begin{array}{l}\text { - Human MSCs were isolated } \\
\text { from gingival papilla (named } \\
\text { GinPaMSCs) } \\
\text { - } \quad \text { Donor details are unclear }\end{array}$ & $\begin{array}{l}\text { - GinPaMSCs cultured with FBS-free } \\
\text { media for } 72 \mathrm{~h} \text { cultures before EV } \\
\text { collection. } \\
\text { CM was collected at } 24 \text { and } 48 \mathrm{~h} \text { of } \\
\text { incubation and centrifuged on a } 100 \\
\text { kDa filter device at } 5000 \times g \text { for } 15 \\
\text { min. The two fractions (i.e., EV: } \mathrm{F}> \\
100 \mathrm{kDa} \text {; free PTX: F < } 100 \mathrm{kDa})\end{array}$ & $\begin{array}{ll}- & \text { DLS } \\
- & \text { NTA } \\
- & \text { TEM }\end{array}$ & $\begin{array}{l}\text { - TEM of exosomes: } 50 \text { to } 500 \mathrm{~nm} \text {. DLS of EV: } \\
\text { 200-300 nm. NTA detected the following } 3 \\
\text { different EV populations: } 135 \mathrm{~nm}, 200-300 \mathrm{~nm} \text {, } \\
\text { and } 435 \mathrm{~nm} \text {. } \\
\text { PTX was presented in PTX-treated } \\
\text { GinPaMSCs-secreted EVs. } \\
\text { - GinPaMSCs-EV / PTX have anti-cancer activity in } \\
\text { human pancreatic carcinoma and squamous } \\
\text { carcinoma cells. }\end{array}$ \\
\hline
\end{tabular}


Table 3. Cont.

\begin{tabular}{|c|c|c|c|c|}
\hline Reference & Cell Source & EV Isolation & EV Characterization & Key Findings \\
\hline Mao et al., 2019 [66] & $\begin{array}{l}\text { - } \quad \text { hGMSCs: gingival tissues were } \\
\text { obtained from five healthy } \\
\text { human subjects aged from } \\
\text { 20-to-40 years, who underwent } \\
\text { routine dental procedures } \\
\text { - } \quad \text { A rat Schwann cell (SC) line } \\
\text { RT4-D6P2T } \\
\text { - } \quad \text { hGMSCs: passage }<6 \\
\text { - }\end{array}$ & $\begin{array}{l}\text { - } \text { hGMSCs cultured in media with } 1 \% \\
\text { exosome-depleted FBS (System } \\
\text { Biosciences, SBI) for } 48 \text { h to collect } \\
\text { CM. } \\
\text { The CM was centrifuged at } 1000 \times g \\
\text { for } 30 \text { min; } 20 \text { mL of culture media } \\
\text { was filtered a Vivaspin } 20 \\
\text { ultrafiltration device }(100 \mathrm{kDa} \text { ) and } \\
\text { centrifuged at } 3000 \times g \text { for } 60 \text { min to } \\
\text { get } 1 \mathrm{~mL} \text { of the concentrated } \\
\text { medium; mixed with } 0.2 \mathrm{~mL} \\
\text { ExoQuick-TC exosome precipitation } \\
\text { solution }(5: 1) \text { and incubated } \\
\text { overnight at } 4{ }^{\circ} \mathrm{C} \text {; centrifuged at } \\
1500 \times g \text { for } 30 \text { min at } 4{ }^{\circ} \mathrm{C}\end{array}$ & $\begin{array}{ll}- & \text { BCA assay } \\
\text { - } & \text { NTA } \\
\text { - } & \text { WB (CD } 63 \text { and CD9) }\end{array}$ & $\begin{array}{l}\text { - } \quad \text { GMSC-derived sEV had a mean size of } 103.8 \pm \\
\text { 2.1 nm by NTA. } \\
\text { in vivo studies mimicking clinical nerve repair } \\
\text { showed that hGMSCs-derived sEV promoted } \\
\text { functional recovery, axonal repair and } \\
\text { regeneration of crush-injured mice sciatic nerves. } \\
\text { in vitro: GMSC-derived EVs promoted } \\
\text { proliferation and migration of Schwann cells, } \\
\text { with upregulated c-JUN, Notch1, GFAP (glial } \\
\text { fibrillary acidic protein), and SRY } \\
\text { (sex-determining region Y)-box } 2 \text { (SOX2). }\end{array}$ \\
\hline $\begin{array}{l}\text { Diomede et al., } 2018 \\
\text { [67] }\end{array}$ & $\begin{array}{l}\text { - } \quad \text { hGMSCs seeded on 3D poly } \\
\text { (lactide) (PLA) scaffolds } \\
\text { Donor: gingival tissue biopsies } \\
\text { were obtained from healthy } \\
\text { adult volunteers with no } \\
\text { gingival inflammation }\end{array}$ & $\begin{array}{l}\text { - After } 48 \mathrm{~h} \text { of incubation, EVs were } \\
\text { collected from hGMSCs at passage } 2 \text {. } \\
\text { centrifuged at } 3000 \times g \text { for } 15 \text { min; } 2 \\
\text { mL ExoQuick TC was added to } 10 \\
\text { mL CM and incubated overnight at } \\
4{ }^{\circ} \mathrm{C} ; 1500 \times g \text { for } 30 \text { min to sediment } \\
\text { the EVs } \\
\text { EVs were engineered with PEI (MW } \\
25,000 \text { ). }\end{array}$ & $\begin{array}{ll}- & \text { DLS } \\
- & \text { AFM } \\
\text { - } & \text { WB (CD9, CD63, } \\
& \text { CD81, and TSG101) }\end{array}$ & $\begin{array}{l}\text { - } \quad \text { DLS of hGMSCs-EVs: } 93 \pm 24 \mathrm{~nm} \text { and } 1200 \pm \\
400 \mathrm{~nm} \text {; engineered hGMSCs-PEI-EV: } 250 \pm 50 \\
\text { nm and } 3600 \pm 500 \mathrm{~nm} \text {. } \\
\text { EV and PEI-EV increased calcium deposits after } 6 \\
\text { weeks of osteogenic differentiation in hGMSCs, } \\
\text { with increased RUNX2 and BMP2/4 gene and } \\
\text { protein expression. } \\
\text { RNA sequencing of the transcriptome of } \\
\text { hGMSCs, EV and PEI-EV revealed that } 31 \text { genes } \\
\text { were differentially expressed between groups. } \\
\text { GO analysis showed that these } 31 \text { genes involved } \\
\text { in "regulation of ossification" and "ossification" } \\
\text { were upregulated in the PEI-EV group compared } \\
\text { to hGMSCs group through the TGF- } \beta \text { signaling. } \\
\text { in vivo results showed that PEI-EV with/without } \\
\text { hGMSCs in PLA scaffolds enhanced bone and } \\
\text { blood vessels formation in a rat cortical calvaria } \\
\text { defect by histology and microCT. }\end{array}$ \\
\hline
\end{tabular}

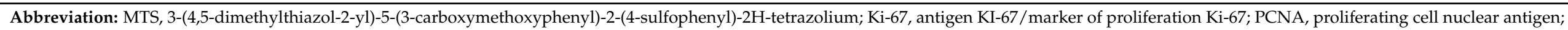

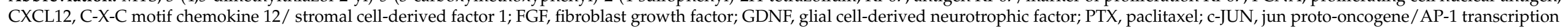
factor subunit; Notch1, Notch homolog 1(translocation-associated). 
RNA sequencing data from Silvestro et al. showed that hGMSCs-EV comprises 15,380 genes (for interleukins, TGF- $\beta$, BMPs, GDFs, Wnt, VEGF, FGF, and neurotrophins), and 1155 non-coding RNA (lncRNAs and miRNAs-miR1302, miR451, miR24, miR219 and miR194) [64]. The miRNA microarray data from Nako et al. [61] showed that 655 universal differentially expressed miRNAs were found in Exo-TNF compared to Exo-Ctrl, particularly miR-1260b (ranked in the top three of the most highly upregulated miRNAs, by using TNF- $\alpha$ preconditioning). RNA sequencing from Diomede et al. [67] demonstrated that 31 ossification genes were enhanced in hGMSCs-PEI-EV compared to hGMSCs-EV through the TGF- $\beta$ signaling pathway.

The in vitro functional assays showed that hGFs/hGMSCs-sEV facilitates cell proliferation (in hGFs [62] and Schwann cells line [66]), anti-osteoclastogenic [61] and osteogenic differentiation (in hBMSCs [63] and hGMSCs [67]), as well as an anti-carcinogenesis effect (in human pancreatic carcinoma and squamous carcinoma cells [65]). This may be mediated by an miR-1260b/Wnt 5A/RANKL pathway [61], miR-23a/CXCL12 axis [63], interleukins, TGF- $\beta$, BMPs, GDFs, Wnt, VEGF, FGF, and neurotrophins [64], and TGF- $\beta$ signaling [67].

In their in vivo investigations, Nakao et al. [61] created a ligature-induced periodontitis mice model, and locally injected hGMSCs-sEV or TNF- $\alpha$-preconditioned GMSC-derived exosomes (hGMSCs-sEV-TNF) into the palatal gingiva of the ligated second maxillary molar. One week post-injection, both the interventions significantly reduced periodontal bone loss compared to the PBS control group, while hGMSCs-sEV-TNF further reduced the distance from the cementoenamel junction to the alveolar bone crest (CEJ-ABC) and the number of tartrate-resistant acid phosphatase (TRAP)-positive osteoclasts, indicating an anti-osteoclastic property for hGMSCs-sEV [61]. Moreover, Mao et al. [66] transplanted hGMSCs-sEV-loaded gelfoam sheets into the crush-injury sites of sciatic nerves in C57BL/6J mice, and the EV group had comparable beneficial effects on the functional recovery of the injured sciatic nerves of mice compared to the hGMSCs group. Further, hGMSCs-sEV enhanced the expression of neuronal and Schwann cell markers ( $\beta$-tubulin III and S100 calcium-binding protein B-S100B) at one-month post-injury, compared with hGMSCs controls, suggesting that hGMSCs-sEV can promote neuron regeneration in vivo. Diomede et al. [67] loaded hGMSCs-EV or hGMSCs-PEI-EV into 3D-printed PLA scaffolds with/without hGMSCs, and transplanted them into rat calvaria defects for 6 weeks. Both the hGMSCs-EV and hGMSCs-PEI-EV groups enhanced bone and blood vessel formation, yet hGMSCs-PEI-EV performed better than the EV group.

In summary, the EV diameter from hGFs/hGSMCs is different among studies, ranging from $50 \mathrm{~nm}$ to $1600 \mathrm{~nm}$. EV-mRNAs and EV-miRNAs [61,64,67] may contribute to their in vitro and in vivo function in cell proliferation [62,66], and reduce bone resorption [61], osteogenic differentiation [63,67] and nerve regeneration [66]. More in vivo studies are required in order to explore the function of EV from gingival tissue-derived cells.

\subsection{Human Dental Pulp Cells (hDPSCs)-sEV}

Table 4 summarizes nine studies investigating EV from human primary DPSCs [68-76], with three of these including in vivo models $[69,72,76]$. Cells were isolated from donors who were 24-41 years old [69], 16-25 years old [70], 20 years old [71], 19-28 years old [73], 22-36 years old [75], or an unclear donor age [68,72,74,76]. The cells at passage 2 [71], passage 3-6 [70], passage $<4$ [76], passage 3-7 [75], passage 3-5 [73], or unclear passage number $[68,69,72,74]$ were used in these studies. Prior to CM collection, the cells were cultured in EV-depleted FBS [68,70-73] or FBS starvation [69,74-76]. The mode size of hPDSCs-sEV was smaller than $<200 \mathrm{~nm}$ in most studies [68-72,75], with one study reporting 50-400 $\mathrm{nm}$ [72], 80-400 $\mathrm{nm}$ [73], and 30-250 $\mathrm{nm}$ [74], and unclear EV size [76]. 
Table 4. The isolation, characterization, and function of hDPSCs-EV.

\begin{tabular}{|c|c|c|c|c|}
\hline Reference & Cell Source & EV Isolation & $\begin{array}{l}\text { EV } \\
\text { Characterization }\end{array}$ & Key Findings \\
\hline $\begin{array}{l}\text { Faruqu } \\
\text { et al., } \\
2020 \\
{[68]}\end{array}$ & $\begin{array}{l}\text { Human dental pulp } \\
\text { pluripotent-like stem cells } \\
\text { (hDPPSCs) from healthy } \\
\text { human third molars extracted } \\
\text { for orthodontic and } \\
\text { prophylactic reasons } \\
\text { - Umbilical cord-derived } \\
\text { mesenchymal stem cells } \\
\text { The passage is not mentioned }\end{array}$ & $\begin{array}{l}\text { - } \\
\text { ultracentrifugation at } 100,000 \times g \text { for } 18 \mathrm{~h} \text { at } \\
4{ }^{\circ} \mathrm{C} \text {. } \\
\text { CM was filtered through } 0.22 \mu \mathrm{m} \text { filter, mixed } \\
\text { with sucrose solution with } 25 \% w / w \text { in } \\
\text { deuterium oxide }(\mathrm{D} 2 \mathrm{O} \text { ) and ultracentrifugation } \\
\text { at } 100,000 \times g \text { for } 1.5 \mathrm{~h} \text { at } 4{ }^{\circ} \mathrm{C} \text { and another } \\
100,000 \times g \text { for } 1.5 \mathrm{~h} \text { at } 4{ }^{\circ} \mathrm{C} \text {. }\end{array}$ & $\begin{array}{l}\text { - } \quad \text { NTA } \\
\text { Dot blot (CD9, } \\
\text { CD63, alix, } \\
\text { TSG101, and } \\
\text { calnexin) }\end{array}$ & $\begin{array}{l}\text { - } \mathrm{sEV} \text { from hDPPSCs spheroids culturing in KnockOut }{ }^{\mathrm{TM}} \\
\text { serum replacement (KO-medium) at both day } 1-12 \text { and } \\
\text { day } 13-24 \text { samples were detected similar particle sizes } \\
(168.7 \pm 7.2 \mathrm{~nm} \text { and } 156 \pm 7.6 \mathrm{~nm})\end{array}$ \\
\hline $\begin{array}{l}\text { Zhou } \\
\text { et al., } \\
2020 \\
{[69]}\end{array}$ & $\begin{array}{l}\text { - } \quad \text { hDPSCs } \\
\text { Donor: } 5 \text { healthy donors (male: } \\
\text { 2; female: 3; age: } 24 \sim 41 \text { years) } \\
\text { and periodontitis teeth }(\mathrm{n}=6) \text {, } \\
\text { named H-DPSCs and P-DPSCs } \\
\text { - } \quad \text { Passage } 3 \sim 5 \\
\text { H-DPSCs and } \\
\text { P-DPSCs-derived EVs are } \\
\text { named H-EV and P-EV. }\end{array}$ & $\begin{array}{l}\text { - At } 90 \% \text { confluence, hDPSCs were washed three } \\
\text { times with PBS prior to culturing with } \\
\text { serum-free media for } 48 \mathrm{~h} \text {. } \\
\text { CM was centrifuged at } 300 \times g \text { for } 10 \mathrm{~min} \text {; } \\
2000 \times g \text { for } 10 \text { min; centrifuged at } 10,000 \times g \text { for } \\
30 \mathrm{~min} \text {; ultracentrifuged at } 100,000 \times g \text { for } 70 \\
\text { min; washed with PBS at } 100,000 \times g \text { for } 70 \mathrm{~min}\end{array}$ & $\begin{array}{l}\text { TEM } \\
\text { NTA } \\
\text { WB (alix, } \\
\text { HSP70, CD9, } \\
\text { CD63 and } \\
\text { CD81) } \\
\text { BCA assay }\end{array}$ & $\begin{array}{l}\text { Both H-EV and P-EV sizes ranged from } 30 \text { to } 200 \mathrm{~nm} \text {. } \\
\text { hPDSCs-sEV from periodontitis patients promoted } \\
\text { endothelial cells proliferation and angiogenesis with } \\
\text { higher expression levels of VEGF and AngII } \\
\text { genes/proteins compared with hPDSCs-sEV from healthy } \\
\text { patients. } \\
\text { in vivo: The vascularization of mouse skin defects and } \\
\text { wound healing were promoted by both H-EV and P-EV, } \\
\text { while the treatment with the latter brought a faster } \\
\text { repairing process, as well as the formation of fresh vessels. }\end{array}$ \\
\hline $\begin{array}{l}\text { Ivica } \\
\text { et al., } \\
2020 \\
{[70]}\end{array}$ & $\begin{array}{l}\text { hDPSCs from healthy third } \\
\text { molars ( } \mathrm{n}=3,16 \text { to } 25 \text { years } \\
\text { old) were extracted } \\
\text { Human bone marrow-derived } \\
\text { mesenchymal stem cells } \\
\text { (HBMMSCs). Passage 3-6 }\end{array}$ & $\begin{array}{l}\text { Exosome-free medium (Invitrogen) was used } \\
\text { for hDPSCs culture for } 48 \mathrm{~h} \text { before CM } \\
\text { collection. } \\
\text { CM centrifuged at } 300 \times g \text { for } 10 \mathrm{~min} ; 2000 \times g \\
\text { for } 30 \text { min; total exosome isolation agent } \\
\text { (Invitrogen) was added; the mixture was } \\
\text { centrifuged at } 10,000 \times g \text { for } 30 \text { min }\end{array}$ & $\begin{array}{l}\text { - } \quad \text { TEM } \\
\text { WB (CD9, and } \\
\text { Grp94) }\end{array}$ & $\begin{array}{l}\text { - } \quad \text { hDPSC-sEV ranged from } 45 \text { to } 156 \mathrm{~nm} \text { by TEM, with a } \\
\text { mean size of } 90 \mathrm{~nm} \text {. } \\
\text { hDPSC-sEV encapsulated in fibrin gel promoted } \\
\text { hBMMSCs migration and proliferation. }\end{array}$ \\
\hline
\end{tabular}


Table 4. Cont.

\begin{tabular}{|c|c|c|c|c|}
\hline Reference & Cell Source & EV Isolation & $\begin{array}{l}\text { EV } \\
\text { Characterization }\end{array}$ & Key Findings \\
\hline $\begin{array}{l}\text { Xie et al., } \\
2020 \\
{[71]}\end{array}$ & $\begin{array}{l}\text { - } \\
\text { DDPSCs } \\
\text { aged } 20 \text { years old, free of } \\
\text { periodontal or endodontic } \\
\text { problems. }\end{array}$ & $\begin{array}{l}\text { Exosomes secreted by hDPSCs during the } \\
\text { starvation of } 48 \mathrm{~h} \text { without FBS, marked as EX0. } \\
\text { Osteogenic-induced DPSC-derived exosomes } \\
\text { (OI-DPSC-Ex) after culturing with osteogenic } \\
\text { media with } 15 \% \text { exosome-free FBS. Exosomes } \\
\text { secreted by these osteogenic-induced DPSCs at } \\
\text { days } 5 \text { and } 7 \text { were extracted and marked as EX5 } \\
\text { and EX7. } \\
\text { CM was centrifugated at } 3000 \times g \text { for } 20 \mathrm{~min} \text {; } \\
\text { centrifuged at } 16,500 \times g \text { for } 20 \text { min; filtered } \\
\text { with a } 0.2 \text { micron filter to collect the filtrate; } \\
\text { ultracentrifuged at } 100,000 \times g \text { for } 70 \text { min } \\
\text { Passage } 2\end{array}$ & $\begin{array}{ll}- & \text { TEM } \\
\text { NTA } \\
\text { Flow } \\
\text { cytometry } \\
\text { (CD63 and } \\
\text { CD81) }\end{array}$ & $\begin{array}{l}\text { - TEM and NTA detected that exosomes size range from } 20 \\
\text { to } 120 \mathrm{~nm} \text {. } \\
\text { The OI-DPSC-Ex induced the osteogenic differentiation of } \\
\text { recipient parent hDPSCs via exosomal circPAR1 binding } \\
\text { with hsa-miR-31. }\end{array}$ \\
\hline $\begin{array}{l}\text { Shen } \\
\text { et al., } \\
2020 \\
{[72]}\end{array}$ & $\begin{array}{ll}\text { - } & \text { hDPSCs } \\
\text { - } & \text { Donor: from exfoliated teeth of } \\
\text { - } & \text { healthy donors } \\
\text { Passage not mentioned }\end{array}$ & $\begin{array}{l}\text { 80\% confluent hDPSCs cultured with medium } \\
\text { supplemented with } 10 \% \text { exosome-free FBS } \\
\text { (centrifuged at } 120,000 \times g \text { for } 18 \mathrm{~h} \text { ) for } 3 \text { days. } \\
\text { CM was centrifuged at } 300 \times g \text { for } 10 \text { min; } \\
\text { centrifuged at } 16,500 \times g \text { for } 20 \text { min; } \\
\text { ultracentrifuged at } 120,000 \times g \text { for } 2.5 \mathrm{~h} \text { at } 4{ }^{\circ} \mathrm{C} \\
\text { DPSC-Exo encapsulated in chitosan hydrogel (CS) } \\
\text { was named DPSC-Exo/CS }\end{array}$ & $\begin{array}{ll}- & \text { TEM } \\
\text { - } & \text { NTA } \\
\text { WB (CD9, } \\
\text { HSP70 and } \\
\text { TSG 101) } \\
\text { - Flow } \\
\text { cytometry } \\
\text { (CD 63 and } \\
\text { CD 81) }\end{array}$ & $\begin{array}{l}\text { - NTA of EV: } 50 \text { to } 400 \mathrm{~nm} \text {, peaked at } 155.4 \mathrm{~nm} \text {. } \\
\text { In an in vivo periodontitis mice model, DPSC-Exo/CS } \\
\text { promoted the regeneration of alveolar bone and } \\
\text { periodontal epithelium in the periodontitis mice model } \\
\text { after } 10 \text { days. } \\
\text { DPSC-Exo/CS had anti-inflammatory effects and } \\
\text { facilitated the immune response by switching } \\
\text { macrophages from a pro-inflammatory phenotype to an } \\
\text { anti-inflammatory phenotype at both in vitro and in vivo } \\
\text { mice with periodontitis via hDPSCs-derived exosomal } \\
\text { miR-1246. }\end{array}$ \\
\hline
\end{tabular}

- hDPSCs

- Donor: healthy patients (aged 19-28 years old, $\mathrm{n}=12$ )

Li et al., mpacted third molars

[73] hDPSCs. EV from LPS-treate
- $\quad$ hDPSCs at $70-80 \%$ confluence cultured for $48 \mathrm{~h}$ in media exosome-depleted FBS (Systembio)

- $\quad \mathrm{CM}$ was centrifuged at $500 \times g$ for $10 \mathrm{~min}$ at $4{ }^{\circ} \mathrm{C}$, centrifuged at $2000 \times g$ for $10 \mathrm{~min}$; centrifuged at $10,000 \times g$ for $1 \mathrm{~h}$ at $4{ }^{\circ} \mathrm{C}$ and filtrated through a $0.22 \mu \mathrm{m}$ filter; ultracentrifuged at $100,000 \times g$ for $2 \mathrm{~h}$; ultracentrifuged at $100,000 \times g$ at $4{ }^{\circ} \mathrm{C}$ for $70 \mathrm{~min}$
- $\quad$ BCA assay

- WB (alix, CD $\mathrm{CD} 63$ and

GM130) cells were named LPS-exo

- $\quad$ Passage 3-5
- NTA
- $\quad$ EV: 80-400 nm, peaked at $116 \mathrm{~nm}$

- LPS-treated cells generated more exosomes particles.

- Both exo and LPS-exo facilitated the production of dentin sialoprotein and mineralization of Schwann cells (SCs).

- LPS-exo had a higher promoted proliferation, migration and odontoblast differentiation of Schwann cells (SCs) compared to Exo only, with increased DSPP, DMP1, OCN and RUNX2 gene expression after 14 days. 
Table 4. Cont.

\begin{tabular}{|c|c|c|c|c|}
\hline Reference & Cell Source & EV Isolation & $\begin{array}{l}\text { EV } \\
\text { Characterization }\end{array}$ & Key Findings \\
\hline $\begin{array}{l}\text { Ji et al., } \\
2019 \\
{[74]}\end{array}$ & $\begin{array}{l}\text { hPDSCs were isolated from } \\
\text { healthy dental pulp tissues } \\
\text { and }(\mathrm{n}=8) \text { from the } \\
\text { caries-free teeth that need to be } \\
\text { extracted due to orthodontics } \\
\text { hBMMSCs were isolated from } \\
\text { bone marrow aspirates of } \\
\text { healthy people }(\mathrm{n}=8) \text {. }\end{array}$ & $\begin{array}{l}\text { At } 80 \% \text { confluence, the medium was replaced } \\
\text { with a serum-free medium for } 48 \mathrm{~h} \text { before } \mathrm{CM} \\
\text { collection. } \\
\text { The } \mathrm{CM} \text { was centrifuged at } 300 \times g \text { for } 10 \mathrm{~min} \text {, } \\
\text { centrifuged at } 16,500 \times g \text { for } 30 \mathrm{~min} \text { at } 4^{\circ} \mathrm{C} \text {; } \\
\text { passed through a } 0.2 \mu \mathrm{m} \text {; ultracentrifuged at } \\
4{ }^{\circ} \mathrm{C} \text { at } 100,000 \times g \text { for } 70 \mathrm{~min} \text {; ultracentrifuged } \\
\text { again at } 4{ }^{\circ} \mathrm{C} \text { at } 100,000 \times g \text { for } 70 \mathrm{~min}\end{array}$ & $\begin{array}{ll}- & \text { TEM } \\
- & \text { NTA } \\
- & \text { BCA } \\
- & \text { WB (CD9 and } \\
\text { CD63) }\end{array}$ & $\begin{array}{l}\text { - } \quad \text { NTA of EV: } 30-250 \mathrm{~nm} \text {, mean size of } 135 \mathrm{~nm} \text {. } \\
\text { hDPSCs-EV suppressed the differentiation of CD4+ T cells } \\
\text { into T helper } 17 \text { cells (Th17), but stimulated the } \\
\text { polarization of CD4+ T cells into regulatory T cells (Treg). } \\
\text { hDPSCs-EV and hBMMSCs-EV inhibited the secretions of } \\
\text { pro-inflammatory factors (IL-17 and TNF- } \alpha \text { ) and increased } \\
\text { anti-inflammatory factors (IL-10 and TGF- } \beta \text { ) in CD4+ T } \\
\text { cells after 72 h of treatment. } \\
\text { Both hDPSCs-EV and hBMMSCs-EV inhibited } \\
\text { proliferation, but increase the apoptosis of CD4+ T cells. }\end{array}$ \\
\hline $\begin{array}{l}\text { Hu et al., } \\
2019 \\
{[75]}\end{array}$ & $\begin{array}{l}\text { - } \\
\text { DDPSCs } \\
\text { isolated from caries-free teeth } \\
\text { of patients ( } 5 \text { females, age } \\
24-35 \text { years; } 5 \text { males, age } 22-36 \\
\text { years) undergoing extraction } \\
\text { of fully erupted third molars } \\
\text { Passage 3-7 }\end{array}$ & $\begin{array}{l}\text { Exosomes from hDPSCs in either growth } \\
\text { (UN-Exo) or odontogenic differentiation media } \\
\text { (OD-Exo) for } 10 \text { days } \\
\text { - Cells were washed in serum-free PBS and } \\
\text { cultured for } 48 \mathrm{~h} \text { in serum-free media. } \\
\text { The Exo-spin (Cell Guidance) exosome isolation } \\
\text { reagent (no detailed description) }\end{array}$ & $\begin{array}{ll}\text { - } & \text { WB (CD9 and } \\
\text { CD63) } \\
\text { - } \quad \text { TEM }\end{array}$ & $\begin{array}{l}\text { - UN-Exo and OD-Exo range from } 30 \text { to } 150 \mathrm{~nm} \text { in diameter } \\
\text { by TEM. } \\
\text { OD-Exo promoted the odontogenic differentiation in } \\
\text { hDPSCs with increased RUNX2,DMP-1, DSP and ALP } \\
\text { gene expression. } \\
\text { RNA sequencing analysis showed that } 28 \text { microRNAs } \\
\text { significantly changed in OD-Exo isolated under } \\
\text { odontogenic conditions, of which } 7 \text { miRNAs increased and } \\
21 \text { miRNAs decreased. The qRT-PCR analysis showed that } \\
\text { miR-5100 and miR-1260a levels in OD-Exo increased, } \\
\text { while miR-210-3p and miR-10b-5p decreased, which were } \\
\text { consistent with the miRNA sequencing. GO analysis } \\
\text { showed that the differentially expressed miRNAs are } \\
\text { associated with the TGF } \beta 1 \text { pathway. } \\
\text { OD-exo activated the TGF } \beta 1 \text { pathway by upregulating } \\
\text { TGF } \beta 1, \text { TGFR1, p-Smad2/3, and Smad4 in DPSCs, } \\
\text { compared to the control group and UN-Exotreated group. } \\
\text { Compared with UN-Exo, miR-27a-5p was expressed } 11 \\
\text { times higher in OD-Exo. } \\
\text { The luciferase reporter assay demonstrated that } \\
\text { miR-27a-5p can target the 3'-UTR of LTBP1 directly. } \\
\text { This suggests that exosomal miRNAs promoted } \\
\text { odontogenic differentiation via the TGF } \beta 1 / \text { smads } \\
\text { signaling pathway by downregulating LTBP1. }\end{array}$ \\
\hline
\end{tabular}


Table 4. Cont.

- $\quad$ Size of EV was not demonstrated.

- The endocytosis of exosomes was

dose-dependent and manner-saturable for both hMSCs and hDPSCs in vitro, which initiated the MAPK pathway through the caveolar endocytic mechanism.

- $\quad$ hDPSCs-EV can bind to fibronectin and type I collagen via an exosomal integrin-mediated process.

- $\quad$ Exosomes were isolated from hDPSCs in either growth (DPSC-Exo) or odontogenic differentiation media (DPSC-OD-Exo) for 4 weeks. Cells were washed in serum-free

Huang

et al.

2016

[76]
- $\quad$ hDPSCs and primary hMSCs are not clearly detailed.

- $\quad$ Both hDPSCs and hMSCs used were passage $<4$ media and cultured for $24 \mathrm{~h}$ in serum-free media before CM collection.

- $\quad$ ExoQuick-TC exosome isolation reagent (non-detailed description)
- WB (CD63 and CD9)

- TEM

DPSC-Exo and DPSC-OD-Exo induce increased expression of odontogenic marker genes in DPSCs in 3D culture within type I collagen hydrogels.

- $\quad$ DPSCs-Exo and DPSC-OD-Exo in a collagen membrane on a filled root canal spaces of human tooth root slices were implanted subcutaneously in athymic nude mice for 2 weeks. DPSC-Exo and DPSC-OD-Exo triggered increased expression of odontogenic differentiation marker proteins DMP1 and DPP, and only the DPSC-OD-Exo group improved active blood vessels formation and endothelial cell marker von Willebrand factor (vWF).

- $\quad$ DPSC-Exo and DPSC-OD-Exo in hMSCs after 48 $\mathrm{h}$ of in vitro treatment increased in the expression levels of several growth factors and ECM proteins along with the transcription factor Runx2.

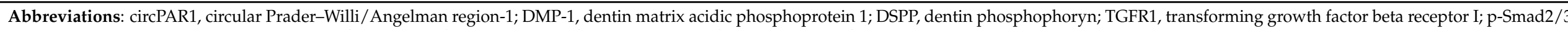

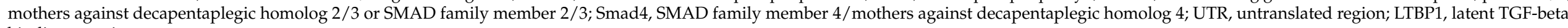
binding protein 
The hPDSCs-EV modulates angiogenesis in endothelial cells [69], migration/proliferation (in hBMMSCs [70], Schwann cells (SCs) [73], and CD4+ T cells [74]), osteogenic differentiation in hDPSCs [71], anti-inflammation (in DPSCs [72] and CD4+ T cells [74]), and odontogenic differentiation of Schwann cells (SCs) [73], hDPSCs [75,76], and hMSCs [76]. This may be regulated through hDPSCs-sEV-circPAR1 binding with hsa-miR-31 [71], hDPSCs-sEV-miR-1246 [72] and hDPSCs-sEV-miR-27a-5p [75]. RNA sequencing data from $\mathrm{Hu}$ et al. [75] demonstrated that 7 increased sEV-miRNAs and 21 decreased sEVmiRNAs were found in odontogenic differentiated hDPSCs-sEV, and these miRNAs are associated with the TGF $\beta 1$ /smads signaling pathway. The authors concluded that sEVmiR-27a-5p can modulate odontogenic differentiation via the TGF $\beta 1$ /smads signaling pathway, by downregulating latent-transforming growth factor beta-binding protein 1 (LTBP1).

With respect to in vivo studies, Zhou et al. [69] created a full-thickness excisional skin wound-healing model in male C57BL/6 mice ( 8 weeks old), and then subcutaneously injected hDPSCs-sEV (200 $\mu \mathrm{g}$ in $100 \mu \mathrm{L})$ from healthy or periodontitis patients derived hDPSCs-sEV (200 $\mu \mathrm{g}$ in $100 \mu \mathrm{L}$ PBS) for 4, 9, and 14 days. Both the sEV groups promoted the wound healing process and vascularization compared to the PBS control group, while hDPSCs-sEV from the periodontitis patients increased the wound closure rate and the number of newly formed microvessels, with more CD31- and VEGF-positive cells compared to the sEV from a healthy patient. Shen et al. [72] established a ligation-induced periodontitis model in 6-8-week-old male C57BL/6J mice, and a chitosan hydrogel (CS) loaded with $50 \mu \mathrm{g}$ of hDPSCs-sEV (hPSDCs-sEV-CS group) was locally injected after ligature removal, with a local injection of PBS or hPSDCs-sEV used as the controls. The results showed that the hDPSCs-sEV-CS group led to increased bone formation, a thick layer of epithelial layers, less inflammatory cells, and a lower amount of TRAP-positive osteoclasts, at 10 days post-treatment. Furthermore, hPSDCs-sEV-CS treatment significantly reduced pro-inflammatory cytokines (IL-23, IL-1 $\alpha$, TNF- $\alpha$, IL-12, IL-1 $\beta$, IL-27, and IL-17), and NF-кB p65 and p38 MAPK signaling, in periodontal tissues compared with other groups. RNA sequencing analysis of the periodontium showed that 7351 differentially expressed genes (DEGs) were found between the hDPSCs-sEV-CS and CS groups. GO term enrichment analysis of the top 200 DEGs demonstrated that they are associated with chemotaxis pathways and the immune response, which were downregulated in the hDPSCs-sEVCS group. Most importantly, hDPSCs-sEV-CS induced macrophages converting from a proinflammatory phenotype to an anti-inflammatory phenotype in the periodontium of periodontitis mice, with more CD206+ anti-inflammatory macrophages and significantly decreased CD86+ in pro-inflammatory macrophages [72]. This indicates that hDPSCssEV can promote bone formation, epithelium re-growth, and reduce inflammation in a periodontitis mice model. Furthermore, Huang et al. [76] loaded hDPSCs-EV into clinicalgrade type I collagen membranes, and then placed them on a human tooth root slice (3-4 $\mathrm{mm}$ in thickness), before subcutaneously transplanting into athymic nude mice for 2 weeks. They resulted in enhanced dental-pulp-like tissues, with increased odontogenic proteins (dentin matrix acidic phosphoprotein 1-DMP1, and dentin phosphophoryn-DSPP) and endothelial cell marker protein (von Willebrand factor-vWF).

To summarize, hDPSCs-EV, ranging from $30 \mathrm{~nm}$ to $400 \mathrm{~nm}$ among nine studies, and containing circRNA [71], miRNAs [72,75], and mRNAs [72], may modulate angiogenesis [69], migration/proliferation [70,73,74], osteogenic differentiation [71], antiinflammation [72,74] and odontogenic differentiation $[73,75,76]$ in recipient cells. Among the three in vivo studies, the skin wound-healing model [69], periodontitis disease model [72], and subcutaneous transplantation [76] were employed, and the results showed that hPDSCs-EV can promote angiogenesis, osteogenesis, dentin-pulp regeneration, and reduce inflammation and osteoclastic activity. Further in vivo studies are required to validate the function of hDPSCs-EV. 


\subsection{SHED/SCAP/DFCs-sEVs}

Table 5 summarizes seven investigations (five in vivo studies) examining sEVs from dental cells, including SCAP [77,78], SHED [79-82], and DFCs [83]. Cells were isolated from 5-8-year-old donors [81], 12-15 years old [77,78], 13-19 years old [83], or unknown age [79,80,82], at passage 3-4 [79], 4-7 [80], 4 [81], 3-6 [82], 5 [83], or unknown [77,78]. EV-depleted FBS $[77,79,81,82]$ and FBS-starvation $[78,80,83]$ were applied for CM collection.

The size of SHED/SCAP/DFCs-sEVs was smaller than $200 \mathrm{~nm}$ in all the studies; these sEVs promote angiogenesis in HUVECs [77,82], anti-inflammation in mBMSCs [80] and chondrocytes [81], osteogenesis in PDLCs [79], mBMSCs [80] and rBMSCs [82], and dentinogenesis in BMMSCs [78,83] in vitro, by the Cdc42 pathway [77], Wnt/ $\beta$-catenin and BMP/Smad signaling pathways [79], miR-100-5p/mTOR pathway [81], and AMPK pathway [82].

The function of SCAP-sEVs was investigated in vivo on gingival soft tissue [77] and dentin-pulp regeneration [78]. Liu et al. [77] created full-thickness circular gingival wounds in C57BL/6J mice, using a biopsy punch (soft tissue defects with a diameter of $2.0 \mathrm{~mm}$ ). Following this, $40 \mu \mathrm{g}$ of SCAP-sEVs, SCAP-siCdc42-sEVs, or PBS, was injected submucosally into the palates of the wounds sites. Seven days post-injection, SCAP-sEVs promoted palatal gingival tissue regeneration by enhancing vascularization in the early phase [77]. Zhuang et al. [78] loaded $50 \mu \mathrm{g} / \mathrm{mL}$ SCAP-sEVs and $4 \times 10^{5}$ BMMSCs with gelatin sponge onto a dentin slice, before subcutaneously transplanting them into immunodeficient mice. Significant dentin-pulp regeneration was observed 12 weeks post-transplantation in the SCAP-sEVs group compared to the PBS control group.

The action of SHED-sEVs on periodontitis disease and periodontal defect in vivo has been investigated in a mouse [80] and rat model [82], respectively. Wei et al. [80] locally injected $20 \mu \mathrm{g}$ of SHED-sEVs into buccal and lingual sides of the first molar once per week, over 2 weeks, in ligature-induced periodontitis mice. After 2 weeks, SHED-sEVs reduced bone loss, with a decreased CEJ-ABC distance compared to the controls. Moreover, $\mathrm{Wu}$ et al. [82] generated a periodontal defect $\left(4 \times 2 \times 1.5 \mathrm{~mm}^{3}\right)$ in their rat model, at the buccal alveolar bone of the first-to-third mandibular molars. SHED-sEVs were loaded into a $\beta$-TCP scaffold before placing them into the periodontal defect for four weeks, resulting in enhanced neovascularization and new bone formation compared to the $\beta-\mathrm{TCP} / \mathrm{PBS}$ scaffold.

In their study, Shi et al. [83] injected gelatin hydrogels (100 $\mu \mathrm{L})$, loaded with LPSDFCs-sEVs (sEVs derived from LPS-treated DFCs) or DFCs-sEVs, into the periodontal pocket of the right maxillary second molar in a ligature-induced periodontitis rat model. The intervention was once a week for up to 8 weeks, and resulted in significantly reduced alveolar bone loss and TRAP-positive osteoclasts, as well as enhanced well-oriented PDL fibers in the LPS-DFCs-sEVs group.

In summary, SHED/SCAP/DFCs-sEVs are smaller than $200 \mathrm{~nm}$, and those containing miR-100-5p [81] may modulate angiogenesis [77,82], inflammation [80,81], osteogenesis $[79,80,82]$, and dentinogenesis $[78,83]$ in vitro. More importantly, five in vivo studies showed that SHED/SCAP/DFCs-sEVs can promote angiogenesis [77,82], dentin-pulp complex [78], alveolar bone [82], and well-organized PDL fiber formation [82]. It is noted that two studies utilized a ligature-induced periodontitis disease model $[80,83]$ and one study used a periodontal defect model [82]. More studies are needed to further validate the in vivo functional role of SHED/SCAP/DFCs-sEVs. 
Table 5. The isolation, characterization, and function of sEVs from SHED, SCAP and DFCs.

\begin{tabular}{|c|c|c|c|c|}
\hline Reference & Cell Source & EV Isolation & $\begin{array}{l}\text { EV } \\
\text { Characterization }\end{array}$ & Key Findings \\
\hline $\begin{array}{l}\text { Liu } \\
\text { et al., } \\
2021 \\
{[77]}\end{array}$ & $\begin{array}{l}\text { - Stem cells from apical papilla (SCAP) } \\
\text { Donor: healthy third molars with } \\
\text { immature roots from healthy donors } \\
\text { aged } 12 \text { to } 15 \text { years } \\
\text { - Passage number is unclear }\end{array}$ & $\begin{array}{l}\text { - SCAP cells were cultured in exosome-free } \\
\text { medium for } 48 \mathrm{~h} \text { and CM was centrifuged at } \\
4^{\circ} \mathrm{C} \text { in an ultracentrifuge at the following three } \\
\text { different speeds: } 3000 \times g \text { for } 20 \mathrm{~min}, 20,000 \times g \\
\text { for } 30 \text { min, and } 120,000 \times g \text { for } 2 \mathrm{~h} \\
\text { - Ultracentrifugation method }\end{array}$ & $\begin{array}{l}-\quad \text { TEM } \\
\text { NTA } \\
\text { WB (CD9, } \\
\text { CD63, and } \\
\text { Alix) }\end{array}$ & $\begin{array}{l}\text { - } \quad \text { sEVs mode: } 120.1 \mathrm{~nm} \text {; mean: } 139.2 \pm 62.5 \mathrm{~nm} \\
\text { in vivo: SCAP-sEVs promoted vascularization to } \\
\text { accelerate tissue regeneration of the palatal } \\
\text { gingiva via Cdc42-mediated vascularization in a } \\
\text { mouse gingival wound healing model. } \\
\text { in vitro: SCAP-sEVs enhanced the cell migration } \\
\text { and angiogenic capacity of HUVECs via } \\
\text { Cdc42-mediated cytoskeletal reorganization. }\end{array}$ \\
\hline $\begin{array}{l}\text { Zhuang } \\
\text { et al., } \\
2021 \\
{[78]}\end{array}$ & $\begin{array}{l}\text { - } \quad \text { SCAP } \\
\text { Donor: Human impacted third molar } \\
\text { with immature roots were collected } \\
\text { from healthy patient }(12-15 \text { years old }) \\
\text { - Passage number is unclear }\end{array}$ & $\begin{array}{l}\text { - SCAP cells at } 60-80 \% \text { confluence were cultured } \\
\text { with serum-free media for } 48 \mathrm{~h} \text { before } \mathrm{CM} \\
\text { collection. } \\
\text { The CM was centrifuged sequentially at } 4{ }^{\circ} \mathrm{C} \text { : } \\
3000 \times g \text { for } 20 \mathrm{~min}, 20,000 \times g \text { for } 30 \mathrm{~min} \text {, and } \\
120,000 \times g \text { for } 2 \mathrm{~h} \text {. } \\
\text { - Ultracentrifugation }\end{array}$ & $\begin{array}{ll}- & \text { TEM } \\
- & \text { NTA } \\
\text { BCA } \\
\text { WB (CD9, and } \\
\text { Alix })\end{array}$ & $\begin{array}{l}\text { - } \quad \text { sEVs peaked at } 120.6 \mathrm{~nm} \text {. } \\
\text { SCAP-Exo promoted mouse BMMSC-based } \\
\text { dentine-pulp complex regeneration in vivo and } \\
\text { in vitro dentinogenesis of BMMSCs. }\end{array}$ \\
\hline $\begin{array}{l}\text { Wang } \\
\text { et al., } \\
2020 \\
{[79]}\end{array}$ & $\begin{array}{l}\text { - Stem cells from human-exfoliated } \\
\text { deciduous teeth (SHED) } \\
\text { hPDLCs } \\
\text { - } \quad \text { Donor: age is unclear; pulp tissue from } \\
\text { non-carious primary teeth extracted } \\
\text { from children for orthodontic reasons } \\
\text { Passage: } 3-4\end{array}$ & $\begin{array}{l}\text { - SHED and hPDLCs cells were cultured in } 15 \% \\
\text { and } 10 \% \text { exosome-free media, respectively. } \\
\text { The CM was centrifuged at } 300 \times g \text { for } 10 \mathrm{~min} \text {, } \\
2000 \times g \text { for } 10 \mathrm{~min} \text {, and } 20,000 \times g \text { for } 30 \mathrm{~min} \\
\text { and } 100,000 \times g \text { for } 70 \mathrm{~min} \\
\text { - Ultracentrifugation }\end{array}$ & $\begin{array}{ll}- & \text { TEM } \\
- & \text { BCA } \\
- & \text { NTA } \\
\text { WB (CD9, } \\
\text { CD63, TSG101 } \\
\text { and Calnexin) }\end{array}$ & $\begin{array}{l}\text { DLS revealed that the SHED-sEVs diameter } \\
\text { ranges from } 40 \text { to } 140 \text { nm. } \\
\text { SHED-sEVs promote in vitro osteogenic } \\
\text { differentiation in PDLCs via Wnt/ } \beta \text {-catenin and } \\
\text { BMP/Smad signaling pathways. }\end{array}$ \\
\hline
\end{tabular}


Table 5. Cont.

\begin{tabular}{|c|c|c|c|c|}
\hline Reference & Cell Source & EV Isolation & $\begin{array}{l}\text { EV } \\
\text { Characterization }\end{array}$ & Key Findings \\
\hline $\begin{array}{l}\text { Wei } \\
\text { et al., } \\
2020 \\
{[80]}\end{array}$ & $\begin{array}{l}\text { - } \quad \text { SHED were purchased } \\
\text { Mouse bone marrow stromal cells } \\
\text { (mBMSCs) were isolated from femur } \\
\text { and tibia bone marrow of CD-1 mice } \\
\text { (9-10 months old). } \\
\text { Passage: 4-7 for SHED-sEVs }\end{array}$ & $\begin{array}{l}\text { - At } 70 \% \text { confluence, SHED cells were cultured in } \\
\text { serum-free media for } 24 \mathrm{~h} \text {. } \\
\text { - The CM was collected and centrifuged at } 300 \times \\
g \text { for } 10 \mathrm{~min}, 2000 \times \mathrm{g} \text { for } 10 \mathrm{~min}, 10,000 \times g \text { for } \\
60 \mathrm{~min} \text { before a } 0.22 \mu \mathrm{m} \text { filter. } 100,000 \times g \text { for } \\
70 \text { min twice to pellet sEVs. } \\
\text { - Ultracentrifugation }\end{array}$ & $\begin{array}{ll}\text { - } & \text { TEM } \\
\text { - } & \text { WB (CD63) }\end{array}$ & $\begin{array}{l}\text { - Diameter: } 100 \mathrm{~nm} \\
\text { in vivo: local injection of SHED-sEVs rescued } \\
\text { ligature-induced periodontitis bone loss in mice. } \\
\text { in vitro: SHED-sEVs promoted cell proliferation, } \\
\text { osteogenesis and reduced adipogenesis and } \\
\text { inflammatory cytokines secretion in mBMSCs. }\end{array}$ \\
\hline $\begin{array}{l}\text { Luo } \\
\text { et al., } \\
2019 \\
{[81]}\end{array}$ & $\begin{array}{l}\text { - SHED was purchased from a cell bank } \\
\text { and cells were from nine normal human } \\
\text { deciduous incisors collected from 5- to } \\
\text { 8-year-old individuals. } \\
\text { Chondrocytes were isolated from } \\
\text { cartilage tissues of five patients with } \\
\text { condylar fracture } \\
\text { Passage } 4 \text { for both SHED and } \\
\text { chondrocytes }\end{array}$ & $\begin{array}{l}\text { - SHED cells were confluent before culturing in } \\
\text { exosome-free media for } 48 \mathrm{~h} \text {. } \\
\text { - } \mathrm{CM} \text { was collected and centrifuged at } 4{ }^{\circ} \mathrm{C}: 300 \times \\
\mathrm{g} \text { for } 10 \mathrm{~min}, 2000 \times \mathrm{g} \text { for } 10 \mathrm{~min}, 20,000 \times \mathrm{g} \text { for } \\
30 \mathrm{~min} \text { and } 100,000 \times g \text { for } 70 \mathrm{~min} \\
\text { - } \quad \text { Ultracentrifugation }\end{array}$ & $\begin{array}{ll}- & \text { TEM } \\
\text { NTA } \\
\text { WB (CD9, } \\
\text { CD63 and } \\
\text { TSG101) }\end{array}$ & $\begin{array}{l}\text { - The sizes of SHED-sEVs range from } 30 \text { to } 100 \mathrm{~nm} \text {. } \\
\text { SHED-sEVs inhibited pro-inflammatory } \\
\text { cytokines expression in chondrocytes in vitro via } \\
\text { an exosomal miR-100-5p and mammalian target } \\
\text { of rapamycin (mTOR) pathway. }\end{array}$ \\
\hline $\begin{array}{l}\mathrm{Wu} \\
\text { et al., } \\
2019 \\
{[82]}\end{array}$ & $\begin{array}{l}\text { - } \\
\text { - } \text { cells } \\
\text { - } \quad \text { rBMSCs: femoral bones of SD rats } \\
\text { - Passage: 3-6 (SHED) }\end{array}$ & $\begin{array}{l}\text { Exosome-depleted FBS was obtained after } \\
\text { ultracentrifuging at } 100,000 \times g \text { for } 12 \mathrm{~h} \text {. } \\
\text { CM collection was not clear. } \\
\text { The CM was centrifuged at } 300 \times g \text { for } 10 \mathrm{~min} \text {, } \\
\text { and } 2000 \times g \text { for } 15 \text { min, } 10,000 \times g \text { for } 30 \mathrm{~min} \\
\text { and concentrated using ultrafiltration, followed } \\
\text { by centrifuging at } 100,000 \times g \text { for } 1 \mathrm{~h} \text {. } \\
\text { Ultracentrifugation }\end{array}$ & $\begin{array}{ll}- & \text { TEM } \\
- & \text { NTA } \\
\text { - } & \text { BCA } \\
& \text { CD (CD81, } \\
& \text { TSG101) }\end{array}$ & $\begin{array}{l}\text { D: } 50 \text { to } 200 \mathrm{~nm} \text {, with two peaks, at } 101 \text { and } \\
144 \mathrm{~nm} \text {. } \\
\text { in vitro: SHED-sEVs promoted proliferation, } \\
\text { migration and angiogenesis in HUVECs and } \\
\text { osteogenic differentiation in rBMSCs via } \\
\text { adenosine monophosphate-activated protein } \\
\text { kinase (AMPK) pathway. } \\
\text { in vivo: SHED-sEVs promoted } \\
\text { neovascularization and new bone formation in a } \\
\text { periodontal bone defect rat model. }\end{array}$ \\
\hline
\end{tabular}


Table 5. Cont.

\begin{tabular}{|c|c|c|c|c|}
\hline Reference & Cell Source & EV Isolation & $\begin{array}{l}\text { EV } \\
\text { Characterization }\end{array}$ & Key Findings \\
\hline $\begin{array}{l}\text { Shi et al., } \\
2020 \\
{[83]}\end{array}$ & $\begin{array}{l}\text { - } \quad \text { Dental follicle cells (DFCs) } \\
\text { Donor: dental follicle tissue obtained } \\
\text { from the immature third molars was } \\
\text { selected in young patients (age } \\
13-19 \text { years). } \\
\text { hPDLCs from chronic periodontitis (age } \\
\text { - } 40-55 \text { years). } \\
\text { Passage: } 5 \text { (for DFCs) }\end{array}$ & $\begin{array}{l}\text { - At } 80 \% \text { confluence, DFCs were treated } \\
\text { with/without LPS for } 24 \mathrm{~h} \text { prior to culturing in } \\
\text { serum-free media for } 48 \mathrm{~h} \text {. } \\
\text { The CM was centrifuged at } 2000 \times g \text { for } 30 \mathrm{~min} \\
\text { and filtered by a } 0.22 \mu \mathrm{m} \text { filter. Then the } \\
\text { supernatant was ultrafiltered using } 100 \mathrm{KD} \\
\text { ultrafiltration at } 5000 \times g \text { or } 30 \text { min. Then total } \\
\text { exosome isolation reagent was added to the } \\
\text { concentrated solution and put into a } 4{ }^{\circ} \mathrm{C} \\
\text { refrigerator overnight and centrifuged at } \\
10,000 \times g \text { for } 1 \mathrm{~h} \text {. } \\
\text { Ultracentrifuge }\end{array}$ & $\begin{array}{ll}\text { - } & \text { TEM } \\
\text { - } & \text { NTA } \\
& \text { WB (CD63 } \\
& \text { and TSG101) }\end{array}$ & $\begin{array}{l}\text { - The diameter of DFCs-sEVs was peaked at } \\
\text { 120nm. } \\
\text { LPS precondition increased the secretion of sEV } \\
\text { from DFCs. } \\
\text { in vitro: LPS-DFCs-sEVs promoted proliferation, } \\
\text { migration and osteogenic differentiation in } \\
\text { periodontitis derived hPDLCS. } \\
\text { in vivo: LPS-DFCs-sEVs enhanced orientated } \\
\text { periodontal ligament formation, periodontal bone } \\
\text { formation, as well as reduced TRAP-positive } \\
\text { osteoclasts cells and RANKL/OPG expression. }\end{array}$ \\
\hline
\end{tabular}

Abbreviations: Cdc42, cell division control protein 42 homolog; RANKL/OPG, receptor activator of nuclear factor kappa-B ligand/osteoprotegerin. 


\section{Summary and Discussion}

Periodontal cells (PDLCs/SCAP and GFs/GMSCs) and dental pulp (DPSCs/SHED)derived EVs can play an important role in augmenting the function of recipient cells, such as proliferation and osteo/odontogenic differentiation, as well as anti-inflammation and anti-cancer properties [51-83]. In particular, one study of GMSCs-sEVs [61] and DPSCs-sEVs [72], two studies of SHED-sEVs [80,82], and one study of DFCs-sEVs [83] can promote alveolar bone, vasculature and well-organized PDL fibers regeneration, and reduced inflammation in a periodontitis animal model or a periodontal defect model. As such, these EVs may serve as potential 'cell-free' therapeutics to facilitate periodontal regeneration; however, more in vivo studies are required to confirm this concept.

As stated in the latest MISEV 2018 guidelines [6], it is critical to clearly describe the primary cell source (i.e., donor age, health status, gender), primary cell passage number, cell culture conditions (using either EV-depleted FBS or FBS starvation before CM collection), and detailed EV isolation and characterization protocols. Among 33 studies in our review, only two studies used human or mouse cell lines [54,57], and 31 studies isolated EV from primary cells, with only 12 out of 31 studies stating a clear age range for the human or mouse donors $[51,55,66,69-71,73,75,77,78,81,83]$, and 13 out of 31 studies were unclear about cell passage numbers $[55,57,58,60,63,65,67-69,72,74,77,78]$. Since FBS is largely EV contaminated, EV-depleted FBS or FBS starvation should be used for cell culture before CM collection. EV-depleted FBS was used in 12 studies [61,63,66,68,70-73,77,79,81,82], FBS starvation in 8 studies $[65,69,74-76,78,80,83]$, and unclear cell culture conditions in 11 studies. Although all the studies used the two most common sEV (or exosome) isolation methods (precipitation and ultracentrifugation), the EV size in these studies (excluding studies with no EV characterization) is not consistent, with 22 studies generating $<200 \mathrm{~nm}$ sEVs $[51,54,55,57,58,61-63,66,68-72,75,77-83]$. This may be attributed to the different CM collection, EV isolation and characterization methods among the studies. Thus, appropriate methods should be chosen to prepare CM, and isolate and characterize cell-derived EV according to the MISEV guidelines. Our review has defined $<200 \mathrm{~nm}$ EV as sEV (small EV) and unclear size or $>200 \mathrm{~nm}$ as simply EV.

Among 33 studies, 12 studies performed in vivo research to investigate the EV function of hPDLCs-sEV [56,59,60], hGMSCs-EV [66,67], hDPSCs-EV [69,72,76], SCAP-sEVs [77,78], SHED-sEVs $[80,82]$ and DFCs-sEVs [83]. Furthermore, three studies engineered the EV using polyethyleneimine (PEI), yielding PEI-EV [56,59,67], and all three studies reported that the PEI-EV group enhanced in vivo osteo/odontogenic and angiogenic properties compared to the EV group. Animal studies employed either defect or disease models, such as calvaria defects $[56,59,67]$, nerve injury model [66,67], skin wound-healing model [69], subcutaneous transplantation [76], and multiple sclerosis [60], ligation-induced periodontitis $[69,72,80,83]$ and a periodontal defect [82].

EVs were administrated either by loading into biomaterials, such as collagen membrane [56,59,76], gelfoam sheets [66], gelatin sponge [78] and 3D-printed PLA scaffold [67], or via intravenous administration [60], subcutaneous injection [69], local injection [61,72,80,83], or submucosal injection [77]. More pre-clinical models (i.e., periodontal defects or periodontitis disease models) and EV delivery systems need to be investigated to explore the potential of periodontal cell-derived EV in the regeneration of anatomically complex tissues, such as the periodontium.

All of the above factors are critical for a successful therapeutic outcome; thus, it is of great importance to follow the relevant guidelines and consider the above-discussed variables with more comparisons between different parameters.

\section{Conclusions and Future Perspectives}

This review demonstrates that $\mathrm{SEV}$ can be isolated from periodontal and pulp cells, with 11 studies investigated the EV cargos, including sEV-miRNA [52,53,61,63,64,72,75,81], EV-circRNA [51,71], EV-lncRNA [51] and EV-mRNA [67,72]. We summarize the common EV-miRNA and EV-circRNA within periodontal (or dental pulp) cells (Figure 4a,b). 
From the included studies, except for one common EV-miRNA (miR-1260b) between DPSCs/SHED and GFs/GMSCs, there appears to be no common EV-miRNA detected between these cell types (shown in Venn diagram, Figure 4a). We also listed reported EVmiRNAs and EV-circRNAs from PDL(S)Cs-EV and hDPSCs-EV (Figure 4b). However, this needs further confirmation with more studies. Furthermore, 38 EV-miRNAs, 69-557 EV-circRNAs, 254-15,380 EV-mRNAs and 2907-11,581 EV-lncRNAs were reported for EV from periodontal (dental pulp) cells by RNA sequencing analysis. We have outlined that these EVs possess anti-inflammation, osteo/odontogenesis, anti-osteoclastogenesis, angiogenesis and immunomodulatory functions in vitro and in vivo. Thus, we propose that periodontal cell-derived EVs can modulate the cell function via EV cargos (Figure 4c). However, more studies for periodontal cell-derived EVs are required to further confirm this concept.

Given that cell source, CM collection, and EV isolation and characterization are critical in obtaining pure EV populations, future studies should take these factors into account and follow the latest MISEV guidelines. Researchers should consider adding EV purity (EV particles per $\mu \mathrm{g}$ protein), DNase/RNase/proteinase treatment and EV engineering before in vivo therapeutic research. Although current research has not yet standardized these factors, data from all 33 studies in this review suggest that periodontal (dental pulp) cell-derived EVs can function as potential therapeutics to promote periodontal regeneration and impart anti-inflammatory properties. However, investigating the effect of periodontal cell-derived EV on in vivo periodontal regeneration models is required to understand their potential therapeutic role in periodontal regeneration.
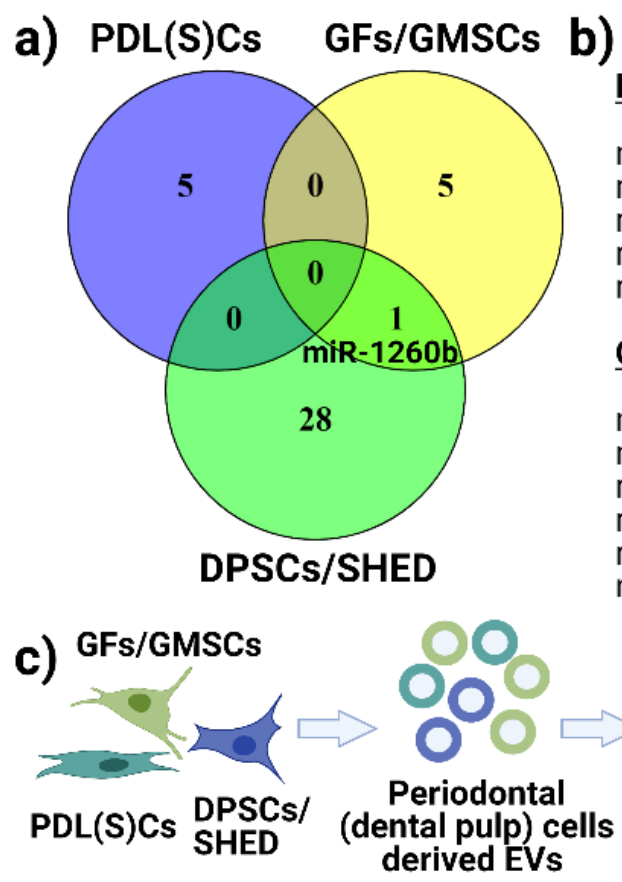

b) EV-miRNAs
PDL(S)Cs
miR-24-2
miR-142
miR-296
miR-335
miR-490
GFs/GMSCs
miR-1260b
miR-1302
miR-451
miR-24
miR-219
miR-194
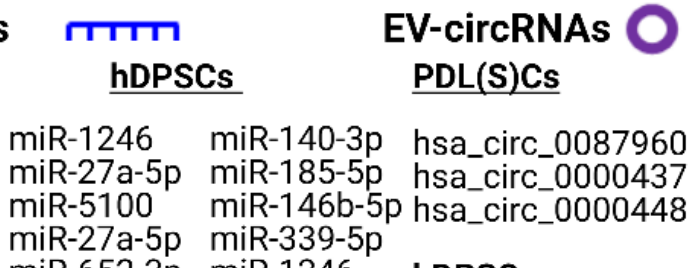

miR-652-3p miR-1246

miR-1260a miR-107

miR-1260b miR-320d

let-7f-1-3p miR-451a

miR-370-3p miR-215-5p

miR-193a-5p miR-126-3p

miR-4792 miR-3687

miR-505-3p miR-31-5p

miR-629-5p miR-210-3p

miR-100-5p miR-1-3p

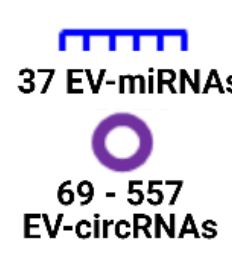

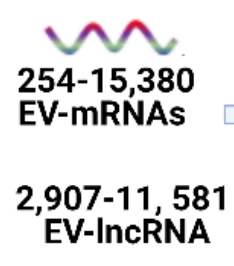

\section{EV-circRNAs} PDL(S)Cs

\section{hDPSCs}

circPAR1

miR-10a-5p

miR-10b-5p

miR-619-5p

miR-27a-5p

\section{Anti-inflammation \\ Osteogenesis \\ Angiogenesis \\ Anti-cancer \\ Anti-osteoclastic \\ Odontogenesis \\ Immuomodulatory}

Figure 4. Summary of EV-miRNAs, circular RNAs $(\mathbf{a}, \mathbf{b})$ and proposed (c) function of periodontal cell-derived EV on recipient cells function. (a) Venn diagram showing no common EV-miRNAs found from PDL(S)Cs, GFs/GMSCs and DPSCs. (b) Listed EV-miRNAs and EV-circRNAs. (c) Proposed mechanism of how periodontal cell-derived EVs modulate inflammation, angiogenesis, osteo/odontogenesis via EV cargos, such as miRNA, mRNAs, lncRNAs, and circRNAs.

Funding: This work was supported by the Australian Dental Research Foundation (ADRF) grant number 534-2019. Karan Gulati is supported by the National Health and Medical Research Council (NHMRC) Early Career Fellowship (APP1140699).

Institutional Review Board Statement: Not applicable.

Informed Consent Statement: Not applicable. 


\section{Data Availability Statement: Not applicable.}

Conflicts of Interest: The authors declare no conflict of interest.

\section{References}

1. Raposo, G.; Stahl, P.D. Extracellular vesicles: A new communication paradigm? Nat. Rev. Mol. Cell Biol. 2019, 20, 509-510. [CrossRef]

2. Johnstone, R.M.; Adam, M.; Hammond, J.; Orr, L.; Turbide, C. Vesicle formation during reticulocyte maturation. Association of plasma membrane activities with released vesicles (exosomes). J. Biol. Chem. 1987, 262, 9412-9420. [CrossRef]

3. Hirsch, J.G.; Fedorko, M.E.; Cohn, Z.A. Vesicle fusion and formation at the surface of pinocytic vacuoles in macrophages. J. Cell Biol. 1968, 38, 629. [CrossRef]

4. Van Niel, G.; D'Angelo, G.; Raposo, G. Shedding light on the cell biology of extracellular vesicles. Nat. Rev. Mol. Cell Biol. 2018, 19, 213-228. [CrossRef] [PubMed]

5. Kalluri, R.; LeBleu, V.S. The biology, function, and biomedical applications of exosomes. Science 2020, 367. [CrossRef]

6. Théry, C.; Witwer, K.W.; Aikawa, E.; Alcaraz, M.J.; Anderson, J.D.; Andriantsitohaina, R.; Antoniou, A.; Arab, T.; Archer, F.; Atkin-Smith, G.K.; et al. Minimal information for studies of extracellular vesicles 2018 (MISEV2018): A position statement of the International Society for Extracellular Vesicles and update of the MISEV2014 guidelines. J. Extracell. Vesicles 2018, 7, 1535750. [CrossRef]

7. Jiao, K.; Walsh, L.J.; Ivanovski, S.; Han, P. The emerging regulatory role of circular RNAs in periodontal tissues and cells. Int J. Mol. Sci. 2021, 22, 4636. [CrossRef] [PubMed]

8. Pan, B.-T.; Teng, K.; Wu, C.; Adam, M.; Johnstone, R.M. Electron microscopic evidence for externalization of the transferrin receptor in vesicular form in sheep reticulocytes. J. Cell Biol. 1985, 101, 942-948. [CrossRef]

9. Boulbitch, A. Deflection of a cell membrane under application of a local force. Phys. Rev. E 1998, 57, 2123. [CrossRef]

10. Bratton, D.L.; Fadok, V.A.; Richter, D.A.; Kailey, J.M.; Guthrie, L.A.; Henson, P.M. Appearance of phosphatidylserine on apoptotic cells requires calcium-mediated nonspecific flip-flop and is enhanced by loss of the aminophospholipid translocase. J. Biol. Chem. 1997, 272, 26159-26165. [CrossRef]

11. Pols, M.S.; Klumperman, J. Trafficking and function of the tetraspanin CD63. Exp. Cell Res. 2009, 315, 1584-1592. [CrossRef] [PubMed]

12. Beinert, T.; Münzing, S.; Possinger, K.; Krombach, F. Increased expression of the tetraspanins CD53 and CD63 on apoptotic human neutrophils. J. Leukoc. Biol. 2000, 67, 369-373. [CrossRef] [PubMed]

13. Han, P.; Bartold, P.M.; Salomon, C.; Ivanovski, S. Salivary small extracellular vesicles associated miRNAs in periodontal status-A pilot study. Int. J. Mol. Sci. 2020, 21, 2809. [CrossRef]

14. Han, P.; Bartold, P.M.; Salomon, C.; Ivanovski, S. Salivary outer membrane vesicles and DNA methylation of small extracellular vesicles as biomarkers for periodontal status: A pilot study. Int. J. Mol. Sci. 2021, 22, 2423. [CrossRef]

15. Han, P.; Lai, A.; Salomon, C.; Ivanovski, S. Detection of salivary small extracellular vesicles associated inflammatory cytokines gene methylation in gingivitis. Int. J. Mol. Sci. 2020, 21, 5273. [CrossRef]

16. Shi, Q.; Huo, N.; Wang, X.; Yang, S.; Wang, J.; Zhang, T. Exosomes from oral tissue stem cells: Biological effects and applications. Cell Biosci. 2020, 10, 108. [CrossRef] [PubMed]

17. Zhan, C.; Yang, X.; Yin, X.; Hou, J. Exosomes and other extracellular vesicles in oral and salivary gland cancers. Oral Dis. 2020, 26, 865-875. [CrossRef] [PubMed]

18. Cocucci, E.; Racchetti, G.; Meldolesi, J. Shedding microvesicles: Artefacts no more. Trends Cell Biol. 2009, 19, 43-51. [CrossRef] [PubMed]

19. Ratajczak, M.Z.; Ratajczak, J. Extracellular microvesicles/exosomes: Discovery, disbelief, acceptance, and the future? Leukemia 2020, 34, 3126-3135. [CrossRef] [PubMed]

20. Muralidharan-Chari, V.; Clancy, J.W.; Sedgwick, A.; D'Souza-Schorey, C. Microvesicles: Mediators of extracellular communication during cancer progression. J. Cell Sci. 2010, 123, 1603-1611. [CrossRef] [PubMed]

21. Tricarico, C.; Clancy, J.; D'Souza-Schorey, C. Biology and biogenesis of shed microvesicles. Small GTPases 2017, 8, 220-232. [CrossRef]

22. Panfoli, I.; Santucci, L.; Bruschi, M.; Petretto, A.; Calzia, D.; Ramenghi, L.A.; Ghiggeri, G.; Candiano, G. Microvesicles as promising biological tools for diagnosis and therapy. Exp. Rev. Proteom. 2018, 15, 801-808. [CrossRef]

23. King, K.; Cidlowski, J. Cell cycle regulation and apoptosis. Annu. Rev. Physiol. 1998, 60, 601-617. [CrossRef]

24. Caruso, S.; Poon, I.K.H. Apoptotic cell-derived extracellular vesicles: More than just debris. Front. Immunol. 2018, 9. [CrossRef]

25. Kakarla, R.; Hur, J.; Kim, Y.J.; Kim, J.; Chwae, Y.-J. Apoptotic cell-derived exosomes: Messages from dying cells. Exp. Mol. Med. 2020, 52. [CrossRef] [PubMed]

26. Opferman, J.T.; Korsmeyer, S.J. Apoptosis in the development and maintenance of the immune system. Nat. Immunol. 2003, 4, 410-415. [CrossRef] [PubMed]

27. Ma, Q.; Liang, M.; Wu, Y.; Ding, N.; Duan, L.; Yu, T.; Bai, Y.; Kang, F.; Dong, S.; Xu, J. Mature osteoclast-derived apoptotic bodies promote osteogenic differentiation via RANKL-mediated reverse signaling. J. Biol. Chem. 2019, 294, 11240-11247. [CrossRef] [PubMed]

28. Ivanovski, S.; Gronthos, S.; Shi, S.; Bartold, P.M. Stem cells in the periodontal ligament. Oral Dis. 2006, 12, 358-363. [CrossRef] 
29. Guo, T.; Gulati, K.; Arora, H.; Han, P.; Fournier, B.; Ivanovski, S. Orchestrating soft tissue integration at the transmucosal region of titanium implants. Acta Biomater. 2021, 124, 33-49. [CrossRef]

30. Shi, X.; Mao, J.; Liu, Y. Pulp stem cells derived from human permanent and deciduous teeth: Biological characteristics and therapeutic applications. Stem Cells Transl. Med. 2020, 9, 445-464. [CrossRef] [PubMed]

31. Kaukua, N.; Shahidi, M.K.; Konstantinidou, C.; Dyachuk, V.; Kaucka, M.; Furlan, A.; An, Z.; Wang, L.; Hultman, I.; ÄhrlundRichter, L.; et al. Glial origin of mesenchymal stem cells in a tooth model system. Nature 2014, 513, 551-554. [CrossRef]

32. Komada, Y.; Yamane, T.; Kadota, D.; Isono, K.; Takakura, N.; Hayashi, S.; Yamazaki, H. Origins and properties of dental, thymic, and bone marrow mesenchymal cells and their stem cells. PLoS ONE 2012, 7, e46436. [CrossRef] [PubMed]

33. Chalisserry, E.P.; Nam, S.Y.; Park, S.H.; Anil, S. Therapeutic potential of dental stem cells. J. Tissue Eng. 2017, 8. [CrossRef]

34. Dan, H.X.; Vaquette, C.; Fisher, A.G.; Hamlet, S.M.; Xiao, Y.; Hutmacher, D.W.; Ivanovski, S. The influence of cellular source on periodontal regeneration using calcium phosphate coated polycaprolactone scaffold supported cell sheets. Biomaterials 2014, 35, 113-122. [CrossRef]

35. Vaquette, C.; Fan, W.; Xiao, Y.; Hamlet, S.; Hutmacher, D.W.; Ivanovski, S. A biphasic scaffold design combined with cell sheet technology for simultaneous regeneration of alveolar bone/periodontal ligament complex. Biomaterials 2012, 33, 5560-5573. [CrossRef] [PubMed]

36. Staples, R.J.; Ivanovski, S.; Vaquette, C. Fibre guiding scaffolds for periodontal tissue engineering. J. Periodontal Res. 2020, 55, 331-341. [CrossRef] [PubMed]

37. Vaquette, C.; Saifzadeh, S.; Farag, A.; Hutmacher, D.W.; Ivanovski, S. Periodontal tissue engineering with a multiphasic construct and cell sheets. J. Dental Res. 2019, 98, 673-681. [CrossRef] [PubMed]

38. Vaquette, C.; Mitchell, J.; Fernandez-Medina, T.; Kumar, S.; Ivanovski, S. Resorbable additively manufactured scaffold imparts dimensional stability to extraskeletally regenerated bone. Biomaterials 2021, 269, 120671. [CrossRef] [PubMed]

39. Han, P.; Ivanovski, S.; Crawford, R.; Xiao, Y. Activation of the canonical Wnt signaling pathway induces cementum regeneration. J. Bone Miner. Res. 2015, 30, 1160-1174. [CrossRef] [PubMed]

40. Han, P.; Lloyd, T.; Chen, Z.; Xiao, Y. Proinflammatory cytokines regulate cementogenic differentiation of periodontal ligament cells by Wnt/Ca(2+) signaling pathway. J. Interferon Cytokine Res. 2016, 36, 328-337. [CrossRef]

41. Gholami, L.; Nooshabadi, V.T.; Shahabi, S.; Jazayeri, M.; Tarzemany, R.; Afsartala, Z.; Khorsandi, K. Extracellular vesicles in bone and periodontal regeneration: Current and potential therapeutic applications. Cell Biosci. 2021, 11, 16. [CrossRef]

42. Gegout, P.Y.; Stutz, C.; Olson, J.; Batool, F.; Petit, C.; Tenenbaum, H.; Benkirane-Jessel, N.; Huck, O. Interests of exosomes in bone and periodontal regeneration: A systematic review. Adv. Exp. Med. Biol. 2020. [CrossRef]

43. Novello, S.; Pellen-Mussi, P.; Jeanne, S. Mesenchymal stem cell-derived small extracellular vesicles as cell-free therapy: Perspectives in periodontal regeneration. J. Periodontal Res. 2021, 56, 433-442. [CrossRef]

44. Witwer, K.W.; Buzás, E.I.; Bemis, L.T.; Bora, A.; Lässer, C.; Lötvall, J.; Nolte-`t Hoen, E.N.; Piper, M.G.; Sivaraman, S.; Skog, J.; et al. Standardization of sample collection, isolation and analysis methods in extracellular vesicle research. J. Extracell. Vesicles 2013, 2, 20360. [CrossRef] [PubMed]

45. Greening, D.W.; Xu, R.; Ji, H.; Tauro, B.J.; Simpson, R.J. A protocol for exosome isolation and characterization: Evaluation of ultracentrifugation, density-gradient separation, and immunoaffinity capture methods. In Proteomic Profiling; Springer: Cham, Switzerland, 2015; pp. 179-209.

46. Böing, A.N.; Van Der Pol, E.; Grootemaat, A.E.; Coumans, F.A.; Sturk, A.; Nieuwland, R. Single-step isolation of extracellular vesicles by size-exclusion chromatography. J. Extracell. Vesicles 2014, 3, 23430. [CrossRef] [PubMed]

47. Karttunen, J.; Heiskanen, M.; Navarro-Ferrandis, V.; Das Gupta, S.; Lipponen, A.; Puhakka, N.; Rilla, K.; Koistinen, A.; Pitkänen, A. Precipitation-based extracellular vesicle isolation from rat plasma co-precipitate vesicle-free microRNAs. J. Extracell. Vesicles 2019, 8, 1555410. [CrossRef] [PubMed]

48. Oliveira-Rodríguez, M.; López-Cobo, S.; Reyburn, H.T.; Costa-García, A.; López-Martín, S.; Yáñez-Mó, M.; Cernuda-Morollón, E.; Paschen, A.; Valés-Gómez, M.; Blanco-López, M.C. Development of a rapid lateral flow immunoassay test for detection of exosomes previously enriched from cell culture medium and body fluids. J. Extracell. Vesicles 2016, 5, 31803. [CrossRef]

49. Oeyen, E.; Van Mol, K.; Baggerman, G.; Willems, H.; Boonen, K.; Rolfo, C.; Pauwels, P.; Jacobs, A.; Schildermans, K.; Cho, W.C. Ultrafiltration and size exclusion chromatography combined with asymmetrical-flow field-flow fractionation for the isolation and characterisation of extracellular vesicles from urine. J. Extracell. Vesicles 2018, 7, 1490143. [CrossRef]

50. Konoshenko, M.Y.; Lekchnov, E.A.; Vlassov, A.V.; Laktionov, P.P. Isolation of extracellular vesicles: General methodologies and latest trends. Biomed. Res. Int. 2018, 2018, 8545347. [CrossRef]

51. Xie, L.; Chen, J.; Ren, X.; Zhang, M.; Thuaksuban, N.; Nuntanaranont, T.; Guan, Z. Alteration of circRNA and lncRNA expression profile in exosomes derived from periodontal ligament stem cells undergoing osteogenic differentiation. Arch. Oral Biol. 2021, 121, 104984. [CrossRef]

52. Zhang, Z.; Shuai, Y.; Zhou, F.; Yin, J.; Hu, J.; Guo, S.; Wang, Y.; Liu, W. PDLSCs regulate angiogenesis of periodontal ligaments via VEGF transferred by exosomes in periodontitis. Int. J. Med. Sci. 2020, 17, 558-567. [CrossRef]

53. Chiricosta, L.; Silvestro, S.; Gugliandolo, A.; Marconi, G.D.; Pizzicannella, J.; Bramanti, P.; Trubiani, O.; Mazzon, E. Extracellular vesicles of human periodontal ligament stem cells contain MicroRNAs associated to proto-oncogenes: Implications in cytokinesis. Front. Genet. 2020, 11, 582. [CrossRef] [PubMed] 
54. Zhao, M.; Dai, W.; Wang, H.; Xue, C.; Feng, J.; He, Y.; Wang, P.; Li, S.; Bai, D.; Shu, R. Periodontal ligament fibroblasts regulate osteoblasts by exosome secretion induced by inflammatory stimuli. Arch. Oral Biol. 2019, 105, 27-34. [CrossRef] [PubMed]

55. Čebatariūnienè, A.; Kriaučiūnaitè, K.; Prunskaitė, J.; Tunaitis, V.; Pivoriūnas, A. Extracellular vesicles suppress basal and Lipopolysaccharide-induced NFkB activity in human periodontal ligament stem cells. Stem Cells Dev. 2019, 28, 1037-1049. [CrossRef] [PubMed]

56. Pizzicannella, J.; Gugliandolo, A.; Orsini, T.; Fontana, A.; Ventrella, A.; Mazzon, E.; Bramanti, P.; Diomede, F.; Trubiani, O. Engineered extracellular vesicles from human periodontal-ligament stem cells increase VEGF/VEGFR2 expression during bone regeneration. Front. Physiol. 2019, 10. [CrossRef] [PubMed]

57. Wang, Z.; Maruyama, K.; Sakisaka, Y.; Suzuki, S.; Tada, H.; Suto, M.; Saito, M.; Yamada, S.; Nemoto, E. Cyclic stretch force induces periodontal ligament cells to secrete exosomes that suppress IL-1 $\beta$ production through the inhibition of the NF- $\mathrm{KB}$ signaling pathway in macrophages. Front. Immunol. 2019, 10. [CrossRef]

58. Kang, H.; Lee, M.-J.; Park, S.J.; Lee, M.-S. Lipopolysaccharide-preconditioned periodontal ligament stem cells induce M1 polarization of macrophages through extracellular vesicles. Int. J. Mol. Sci. 2018, 19, 3843. [CrossRef]

59. Diomede, F.; D’aurora, M.; Gugliandolo, A.; Merciaro, I.; Ettorre, V.; Bramanti, A.; Piattelli, A.; Gatta, V.; Mazzon, E.; Fontana, A. A novel role in skeletal segment regeneration of extracellular vesicles released from periodontal-ligament stem cells. Int. J. Nanomed. 2018, 13, 3805. [CrossRef]

60. Rajan, T.S.; Giacoppo, S.; Diomede, F.; Ballerini, P.; Paolantonio, M.; Marchisio, M.; Piattelli, A.; Bramanti, P.; Mazzon, E.; Trubiani, O. The secretome of periodontal ligament stem cells from MS patients protects against EAE. Sci. Rep. 2016, 6, 38743. [CrossRef]

61. Nakao, Y.; Fukuda, T.; Zhang, Q.; Sanui, T.; Shinjo, T.; Kou, X.; Chen, C.; Liu, D.; Watanabe, Y.; Hayashi, C.; et al. Exosomes from TNF- $\alpha$-treated human gingiva-derived MSCs enhance M2 macrophage polarization and inhibit periodontal bone loss. Acta Biomater. 2021, 122, 306-324. [CrossRef]

62. Yin, S.; Jia, F.; Ran, L.; Xie, L.; Wu, Z.; Zhan, Y.; Zhang, Y.; Zhang, M. Exosomes derived from idiopathic gingival fibroma fibroblasts regulate gingival fibroblast proliferation and apoptosis. Oral Dis. 2020. [CrossRef]

63. Zhuang, X.-M.; Zhou, B. Exosome secreted by human gingival fibroblasts in radiation therapy inhibits osteogenic differentiation of bone mesenchymal stem cells by transferring miR-23a. Biomed. Pharmacother. 2020, 131, 110672. [CrossRef] [PubMed]

64. Silvestro, S.; Chiricosta, L.; Gugliandolo, A.; Pizzicannella, J.; Diomede, F.; Bramanti, P.; Trubiani, O.; Mazzon, E. Extracellular vesicles derived from human gingival mesenchymal stem cells: A transcriptomic analysis. Genes 2020, 11, 118. [CrossRef] [PubMed]

65. Coccè, V.; Franzè, S.; Brini, A.T.; Giannì, A.B.; Pascucci, L.; Ciusani, E.; Alessandri, G.; Farronato, G.; Cavicchini, L.; Sordi, V. in vitro anticancer activity of extracellular vesicles (EVs) secreted by gingival mesenchymal stromal cells primed with paclitaxel. Pharmaceutics 2019, 11, 61. [CrossRef] [PubMed]

66. Mao, Q.; Nguyen, P.D.; Shanti, R.M.; Shi, S.; Shakoori, P.; Zhang, Q.; Le, A.D. Gingiva-derived mesenchymal stem cell-extracellular vesicles activate schwann cell repair phenotype and promote nerve regeneration. Tissue Eng. Part A 2019, 25, 887-900. [CrossRef]

67. Diomede, F.; Gugliandolo, A.; Cardelli, P.; Merciaro, I.; Ettorre, V.; Traini, T.; Bedini, R.; Scionti, D.; Bramanti, A.; Nanci, A. Three-dimensional printed PLA scaffold and human gingival stem cell-derived extracellular vesicles: A new tool for bone defect repair. Stem Cell Res. Ther. 2018, 9, 104. [CrossRef] [PubMed]

68. Faruqu, F.N.; Zhou, S.; Sami, N.; Gheidari, F.; Lu, H.; Al-Jamal, K.T. Three-dimensional culture of dental pulp pluripotent-like stem cells (DPPSCs) enhances Nanog expression and provides a serum-free condition for exosome isolation. FASEB BioAdv. 2020, 2, 419-433. [CrossRef] [PubMed]

69. Zhou, H.; Li, X.; Yin, Y.; He, X.-T.; An, Y.; Tian, B.-M.; Hong, Y.-L.; Wu, L.-A.; Chen, F.-M. The proangiogenic effects of extracellular vesicles secreted by dental pulp stem cells derived from periodontally compromised teeth. Stem Cell Res. Ther. 2020, 11. [CrossRef] [PubMed]

70. Ivica, A.; Ghayor, C.; Zehnder, M.; Valdec, S.; Weber, F.E. Pulp-derived exosomes in a fibrin-based regenerative root filling material. J. Clin. Med. 2020, 9, 491. [CrossRef]

71. Xie, L.; Guan, Z.; Zhang, M.; Lyu, S.; Thuaksuban, N.; Kamolmattayakul, S.; Nuntanaranont, T. Exosomal circLPAR1 promoted osteogenic differentiation of homotypic dental pulp stem cells by competitively binding to hsa-miR-31. BioMed Res. Int. 2020, 2020, 6319395. [CrossRef]

72. Shen, Z.; Kuang, S.; Zhang, Y.; Yang, M.; Qin, W.; Shi, X.; Lin, Z. Chitosan hydrogel incorporated with dental pulp stem cell-derived exosomes alleviates periodontitis in mice via a macrophage-dependent mechanism. Bioact. Mater. 2020, 5, 1113-1126. [CrossRef]

73. Li, J.; Ju, Y.; Liu, S.; Fu, Y.; Zhao, S. Exosomes derived from lipopolysaccharide-preconditioned human dental pulp stem cells regulate Schwann cell migration and differentiation. Connect. Tissue Res. 2019, 62, 277-286. [CrossRef]

74. Ji, L.; Bao, L.; Gu, Z.; Zhou, Q.; Liang, Y.; Zheng, Y.; Xu, Y.; Zhang, X.; Feng, X. Comparison of immunomodulatory properties of exosomes derived from bone marrow mesenchymal stem cells and dental pulp stem cells. Immunol. Res. 2019, 67, 432-442. [CrossRef]

75. Hu, X.; Zhong, Y.; Kong, Y.; Chen, Y.; Feng, J.; Zheng, J. Lineage-specific exosomes promote the odontogenic differentiation of human dental pulp stem cells (DPSCs) through TGF 11 /smads signaling pathway via transfer of microRNAs. Stem Cell Res. Ther. 2019, 10, 170. [CrossRef] [PubMed] 
76. Huang, C.-C.; Narayanan, R.; Alapati, S.; Ravindran, S. Exosomes as biomimetic tools for stem cell differentiation: Applications in dental pulp tissue regeneration. Biomaterials 2016, 111, 103-115. [CrossRef] [PubMed]

77. Liu, Y.; Zhuang, X.; Yu, S.; Yang, N.; Zeng, J.; Liu, X.; Chen, X. Exosomes derived from stem cells from apical papilla promote craniofacial soft tissue regeneration by enhancing Cdc42-mediated vascularization. Stem Cell Res. Ther. 2021, 12, 76. [CrossRef] [PubMed]

78. Zhuang, X.; Ji, L.; Jiang, H.; Liu, Y.; Liu, X.; Bi, J.; Zhao, W.; Ding, Z.; Chen, X. Exosomes derived from stem cells from the apical papilla promote dentine-pulp complex regeneration by inducing specific dentinogenesis. Stem Cells Int. 2020, 2020, 5816723. [CrossRef]

79. Wang, M.; Li, J.; Ye, Y.; He, S.; Song, J. SHED-derived conditioned exosomes enhance the osteogenic differentiation of PDLSCs via Wnt and BMP signaling in vitro. Differentiation 2020, 111. [CrossRef]

80. Wei, J.; Song, Y.; Du, Z.; Yu, F.; Zhang, Y.; Jiang, N.; Ge, X. Exosomes derived from human exfoliated deciduous teeth ameliorate adult bone loss in mice through promoting osteogenesis. J. Mol. Histol. 2020, 51, 455-466. [CrossRef]

81. Luo, P.; Jiang, C.; Ji, P.; Wang, M.; Xu, J. Exosomes of stem cells from human exfoliated deciduous teeth as an anti-inflammatory agent in temporomandibular joint chondrocytes via miR-100-5p/mTOR. Stem Cell Res. Ther. 2019, 10, 216. [CrossRef]

82. Wu, J.; Chen, L.; Wang, R.; Song, Z.; Shen, Z.; Zhao, Y.; Huang, S.; Lin, Z. Exosomes secreted by stem cells from human exfoliated deciduous teeth promote alveolar bone defect repair through the regulation of angiogenesis and osteogenesis. ACS Biomater. Sci. Eng. 2019, 5, 3561-3571. [CrossRef] [PubMed]

83. Shi, W.; Guo, S.; Liu, L.; Liu, Q.; Huo, F.; Ding, Y.; Tian, W. Small extracellular vesicles from lipopolysaccharide-preconditioned dental follicle cells promote periodontal regeneration in an inflammatory microenvironment. ACS Biomater. Sci. Eng. 2020, 6, 5797-5810. [CrossRef] [PubMed] 